MUSICA THEORICA 201616

SCIENTIFIC ARTICLE

Data do recebimento: $25 / 11 / 2016$

Data da aprovação final: 10/01/2017

\title{
Imitative Polyphonic Density and Cadential Plan for Two Motets of the Mid-Sixteen-Century ${ }^{1,2}$
}

\author{
Densidade Polifônica Imitativa e Plano Cadencial \\ em Dois Motetos de Meados do Século Dezesseis
}

\section{Marcos Pupo Nogueira}

Universidade Estadual Paulista (UNESP-IA)

Email: mpuponogueira@gmail.com

\section{Fernando Luiz Cardoso Pereira \\ Universidade Estadual Paulista (UNESP-IA) \\ Email: fcperera@gmail.com}

\begin{abstract}
Magnum haereditatis mysterium" a quattro is one of Willaert's few motets featuring a migrating cantus firmus. By means of a converging strategy involving motivic and cadencial analysis, we found that some words or expressions are intensified by imitative treatment of motives. Two passages of the text are highlighted: templum dei factus est uterus nesciens virum and non est pollutus ex ea carnem assumens, the latter revealing a higher imitative density and constituting the dramatic core of the motet. "Venit vox de coelo" of Clemens non Papa on the passage of the Bible referring to Saul's conversion don't has a cantus firmus, but features a complex imitative polyphonic fabric. One example is particularly eloquent: that which announces the dramatic section, "Shaul, Shaul, why do you persecute me? It is hard for you to kick against the goads" by means of a semi-perfect cadence with a double cantizans-tenorizans parallel-third movement, in a contrasting remodeling of the imitative structure. For both motets the concepts of "Modular Analysis" (Schubert, 2007), "sound grouping" (Nogueira, 2014), "fuga cell” (Milson, 2006), "motivicity" (Rifkin, 1997) and theidentification of phrases from the soggetto (Rivera, 1993) were all central to the structural analysis. Cadence plans and mode analy sis were based on Meier (1988) and Smith (2011). The attributions of syllabic and melodic inflections for both motets were evaluated with primary sources of manuscripts and prints indicate in bibliographic references.
\end{abstract}

Key words: Willaert, Clemens non Papa, imitative polyphony, grouping structure, cadence plan.

\footnotetext{
${ }^{1}$ Research supported by CNPq and CAPES

2 This article is an improvement and enlargement of two communications presented in two conferences. The first, "Valorizing Clemens non Papa: Towards a Polycentric Model for Renaissance Music", at the Boston University in November de 2015. The second at the Nottingham University (United Kingdom) in July of 2016, during the Music Analysis Conference, HAPMAC - History, Analysis, Pedagogy. We are grateful to Professors Joshua Rifkin and Victor Coelho for comments e suggestions in the Boston Conference and to Katelijne Schiltz at the Nottingham University HAPMAC Conference.
} 
Resumo: "Magnum haereditatis mysterium" a quattro é um dos poucos motetos de Willaert que utiliza um cantus firmus migrante. Por meio de uma estratégia que envolve análises motívica e cadencial concluímos que algumas palavras e expressões são intensificadas por um tratamento imitativo dos motivos. Duas passagens do texto são destacadas: templum dei factus est uterus nesciens virum e non est pollutus ex ea carnem assumens, esta última revelando uma maior densidade imitativa e constituindo o núcleo dramático do moteto. "Venit vox de coelo" de Clemens non Papa sobre a passagem da Bíblia que se refere à conversão de Saul, não tem um cantus firmus, mas apresenta uma textura complexa de polifonia imitativa. Um exemplo é particularmente eloquente: aquele que anuncia a seção dramática "Saul, Saul, por que você me persegue? É difícil para você bater-se contra os aguilhões" por meio de uma cadência semi-perfeita com movimento em terça paralela de cantizans-tenorizans duplo, em uma remodelagem contrastante da estrutura imitativa. Para ambos os motetos o conceito de "análise modular" (Schubert, 2007), “agrupamento sonoro" (Nogueira, 2014), "célula de fuga" (Milson, 2006), "motivicidade" (Rifkin, 1997) e a identificação de frase do soggetto (Rivera, 1993), foram todas elas centrais para a análise estrutural. Os modelos de cadência e as análises modais foram baseadas em Meier (1988) e Smith (2011). As atribuições de inflexões silábicas e melódicas para os dois motetos for am avaliadas com as fontes primárias dos manuscritos e das publicações indicadas nas referências bibliográficas.

Palavras-chave: Willaert, Clemens non Papa, polifonia imitativa, estrutura de agrupamento, plano cadencial.

\section{1 - Introduction}

The plainchant for the antiphon "Magnum hereditatis mysterium" can be found in the Liber usualis, transcribed in four articulated verses with additional weak internal articulations:

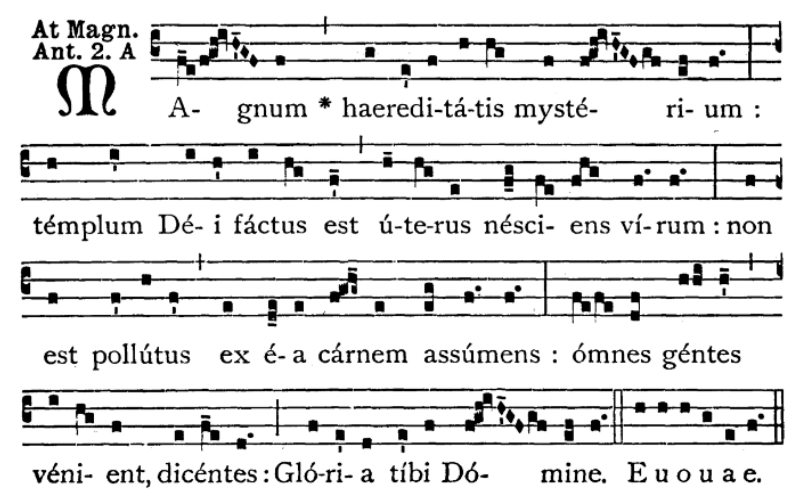

Example 1: The plainchant as transcribed in Liber usualis

This cantus firmus shows an incomplete correspondence with the motet, notably before the segment "carnem assumens". This was detected mainly because of the cadencial plane of the piece. Some typology and ranking for cadences will be presented now for allowing their identification into the motet.

$$
* * *
$$

\section{MUSICA THEORICA}


"Venit vox de celo" by Clemens non Papa appears in a number of anthologies throughout the second half of the $16^{\text {th }}$ century. These primary sources were produced in the form of printed and manuscript partbooks, as well as manuscript choirbooks, alongside with organ tablatures. As many of the sources were later than the printed partbooks that were published up to 1559, we focused our attention on editions prior to this year, except for organ tablatures. Thus we set up a score from sources that were within reach, each one labeled with greek numerals, beginning with the probably earlier Munich choirbook as " $\alpha$ "; Scotto's Venice partbook as " $\beta$ "; Phalèse's Louvain partbook as " $\gamma$ "; the manuscript Kassel partbook, known as a probable Phalèse copy, as " $\delta$ "; the Nuremberg partbook as " $\varepsilon$ " and the Leiden choirbook as " $\varphi$ ".

\begin{tabular}{|c|c|c|c|c|c|c|c|}
\hline year & ty & pe & format & city, country & editor & name & source \\
\hline 1552 & & MS & partbook $^{1}$ & Belgium (Antwerp) & Plantin & "Stonyhurst partbooks" & WhalleyS 23 \\
\hline /after & $\alpha$ & MS & choirbook & Germany (Munich) & Steydl & "Munich choirbook" & MunBS 13 \\
\hline \multirow[t]{3}{*}{1554} & & PT & partbook & Belgium (Louvain) & Phalèse & Lib. 1 cantionum sacrarum & RISM $1554^{1}$ \\
\hline & & PT & partbook & Switzerland (Geneve) & Du Bosc & Secundum liber modulorum & RISM $1554^{13}$ \\
\hline & $\beta$ & PT & partbook $^{2}$ & Italy (Venice) & Scotto & Motetti del laberinto Lib. 4 & RISM $1554^{16}$ \\
\hline 1555 & $\gamma$ & PT & partbook & Belgium (Louvain) & Phalèse & Lib. 1 cantionum sacrarum & RISM $1555^{2}$ \\
\hline /after & $\delta$ & MS & partbook & Germany (Kassel) & Heugel & "Kassel partbooks" & KasL 91 \\
\hline \multirow[t]{2}{*}{1556} & & MS & choirbook $^{3}$ & Germany (Pirna) & Weissenberger & "Pirna choirbook" & DresSL Pirna ${ }^{7}$ \\
\hline & & MS & partbook $^{4}$ & Bohemia (H. Krávolé) & $(?)$ & "Hradec Krávolé partbook" & HradKM 29 \\
\hline \multirow[t]{3}{*}{1559} & & PT & partbook $^{5}$ & Switzerland (Geneve) & Sylvius & Quartus liber modulorum & RISM $1559^{5}$ \\
\hline & $\varepsilon$ & PT & partbook & Germany (Nurenberg) & Berg \& Neuber & 2a pars magni operis musici & RISM 1559 \\
\hline & $\varphi$ & MS & choirbook & Netherlands (Leiden) & de Blauwe & "Leiden Choirbooks" & LeidGA 1439 \\
\hline 1575 & & PT & organ tab. & Germany (Leipzig) & Beyer & $\begin{array}{c}\text { Ein new kunstlich } \\
\text { Tabulaturbuch (Ammerbach) }\end{array}$ & RISM $1575^{17}$ \\
\hline 1585 & & MS & organ tab. & Germany (Tübingen) & several & "Tübingen tablature" & BasU F.IX.44 \\
\hline
\end{tabular}

Table 1. "Venit vox de coelo": some primary sources

\section{2 - Analytic tools and its definitions}

\subsection{Cadences: typology and ranking}

Ancient theorists as Zarlino, Dressler, Pontio, Aron and many others first devised analytical techniques for cadences. They produced a varied terminology that was critically compiled by the musicologist Bernhard Meier to establish further relations with texture and text analysis. This was generally treated in a four-voice model (a voce piena), which included stereotypical melodic movements for individual voices identified in red as follows (Examples 2 - 5): 


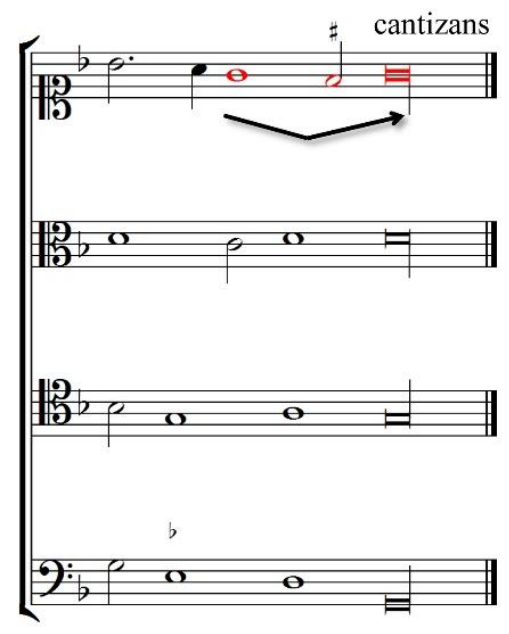

Example 2. Cantizans, with a syncopated leading tone

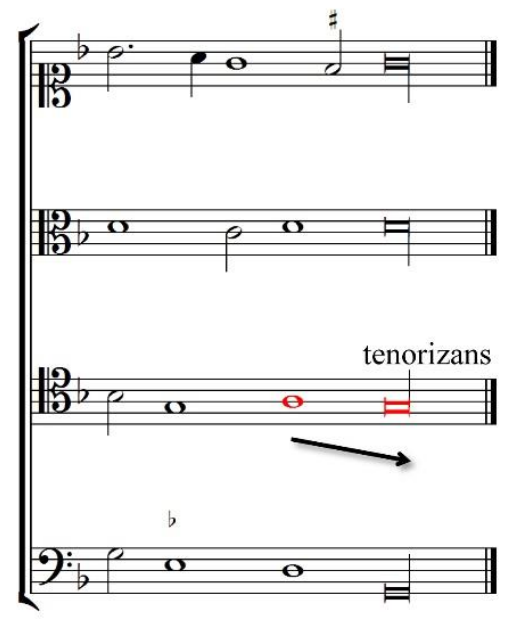

Example 4. Tenorizans, always descending a degree to the finalis

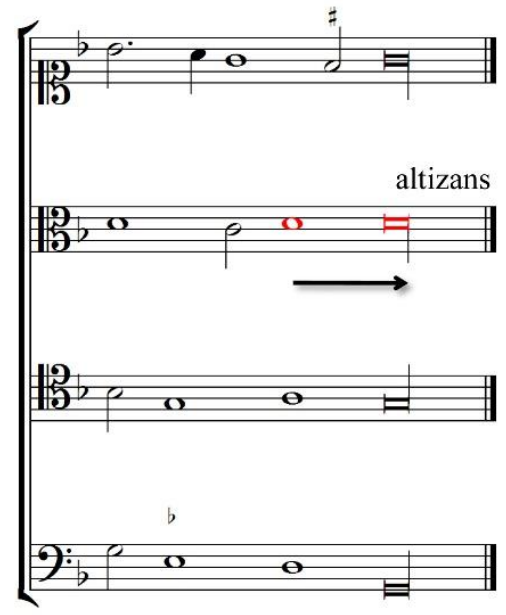

Example 3. Altizans, generally maintaining the fifth degree

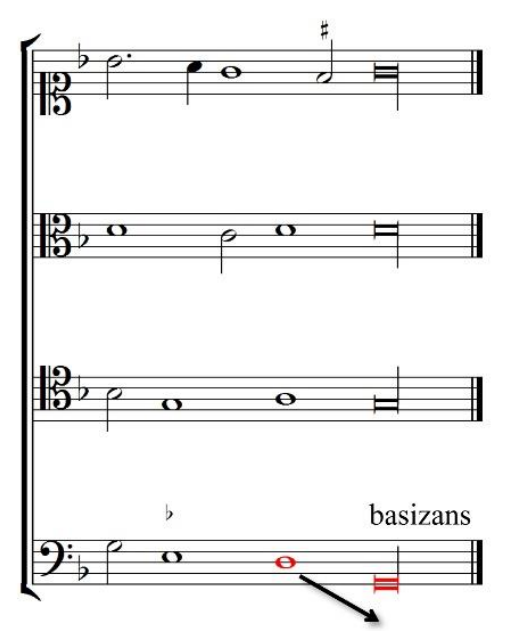

Example 5. Basizans, reaches the finalis by a descending or ascending leap

The cantizans-tenorizans interaction promotes a resolution of a major sixth towards an octave, this being a first reference level that we call $\mathrm{C} / \mathrm{T}$-cadence (Example 6, considering only the red notes). Depending on the mode, it will be necessary to add ficta in one of these movements to guarantee the major sixth; when it happens on cantizans, as in the Example 6, in transposed hypodorian mode, this is named clausula vera. According to Dressler, whereas this represents a semi-perfect cadence, a perfect one is formed when the bass is considered, upgrading it to our second reference level (Example 7). 


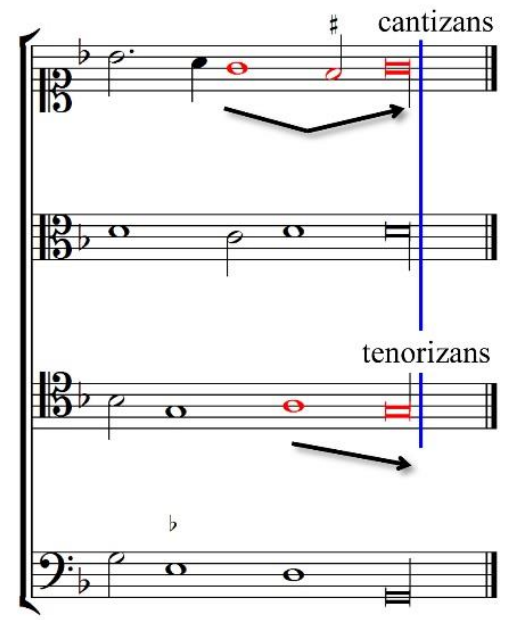

Example 6. Clausula vera, semi-perfect

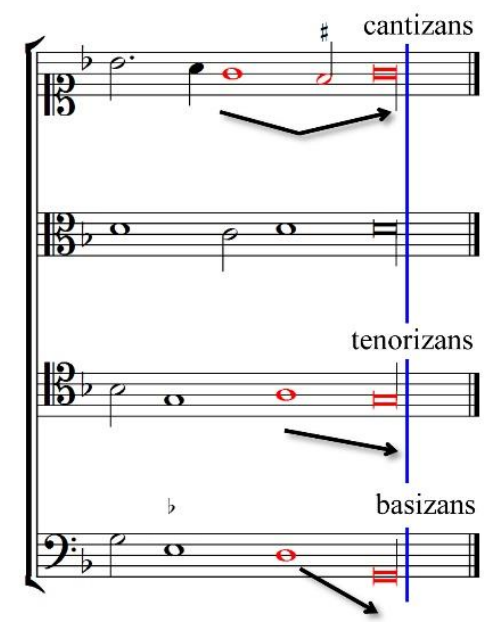

Example 7. Perfect cadence

This can be further promoted to a full cadence if the altus is considered in the cadence, representing our third reference level (Example 8).

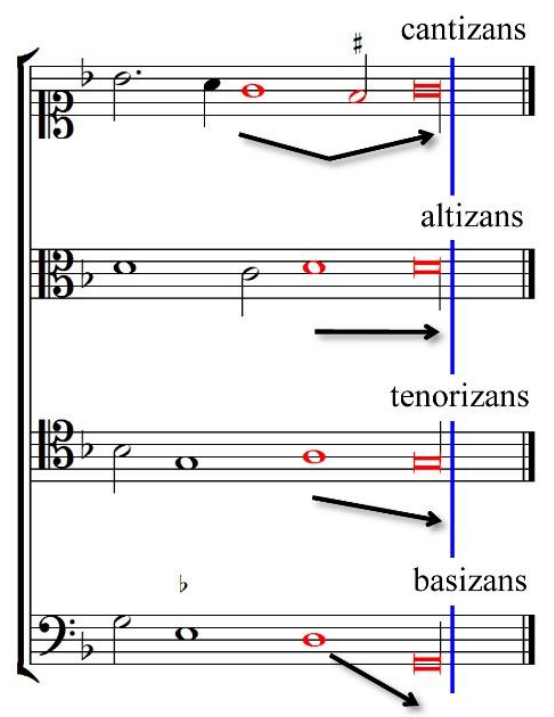

Example 8. Full cadence

Ficta could also be added to a tenorizans, providing a clausula frigia (Example 9). This one cannot undertake a perfect pattern, being restricted to the semi-perfect cadence even if altus is considered (Example 10). Is good to remember that if any ficta occurs we will not have any leading tone in the cadence, debasing it to a clausula doria. 


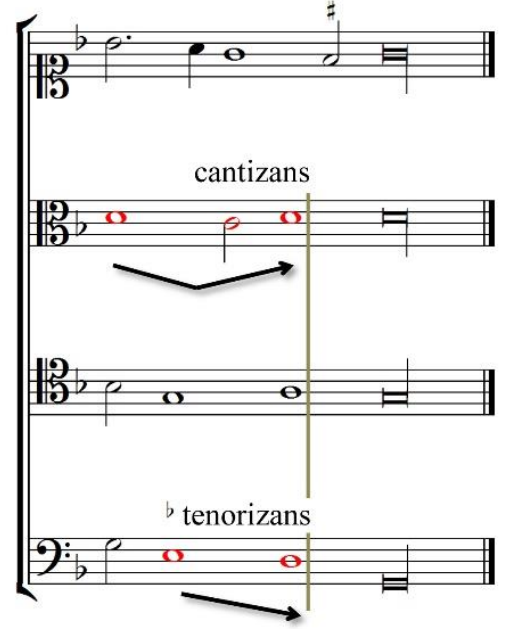

Example 9. Clausula frigia

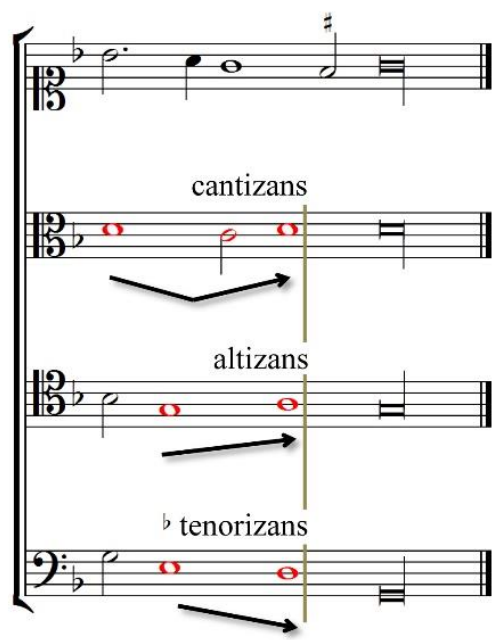

Example 10. Semi-perfect cadence

The coordination of clausula frigia and vera in a major articulation can be said a staggered cadence, consisting in a fourth reference level. A simple condition for this is a common note shared by the two processes (Example 11).

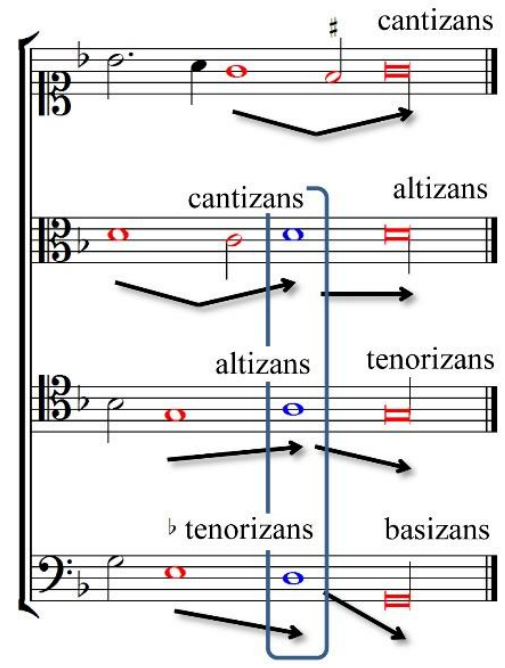

Example 11. Staggered cadence

Any disturbance in the reference levels prompts the fleetingness of its perception, as the cadence becomes less perennial. For example, ornate cadences are generally made of a cantizans diminuta (Example 12), whereas an incomplete cadence depends on a tenorizans melodic deviation (Example 13) or interruption by a rest (Example 13). When the latter happens to basizans or even an altizans, this is called fuggita (Example 13): 


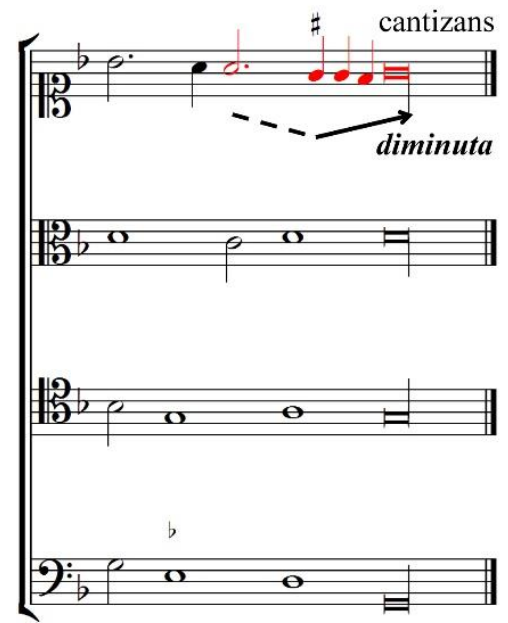

Example 12. Cantizans diminuta

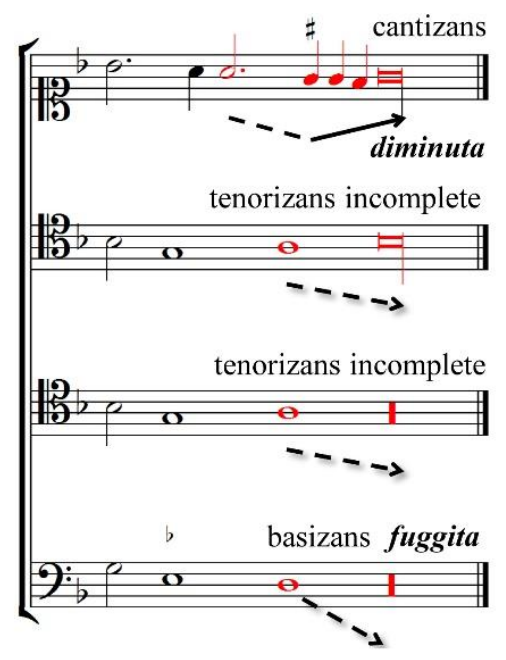

Example 13. All possibilities of disturbance

Turning upside-down the $\mathrm{C} / \mathrm{T}$ cadence also changes its perception; it remains perennial yet not stereotypical (Example 14):

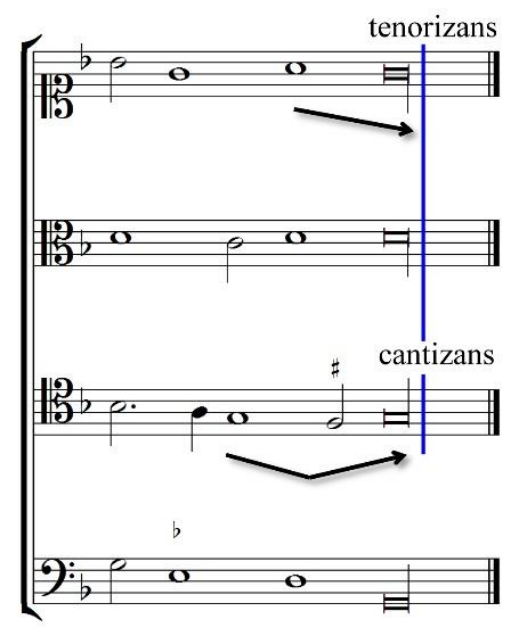

Example 14. Turning upside-down the C/T-cadence

Cadence ranking depends on the kind of mode for the piece. For "Magnum hereditatis mysterium", the mode is hypodorian, transposed by default. Cadence types were selected by specificity to resolution tones according to ancient theorists, going from the finalis $\mathrm{G}$ to less important tones as D and B flat in this case; they could be said primera, segunda and intermedia according to Montanos. Cadences on $\mathrm{C}$ or $\mathrm{F}$ are much less important for Pontio and Dressler, whereas phrigian and plagal cadences are rarely included in rankings, although being treated by Zarlino, Burmeister and others. 


\subsection{Grouping structures: graphic tools and definitions of analytical concepts}

To clarify structural analysis, graphic tools called grouping structures were devised to describe imitative or non-imitative processes. Imitative processes are defined by shared configuration patterns of motives marked with horizontal solid lines and connected by diagonals. Solid lines indicate regular imitative patterns named expositive groups (Figure 1), whereas those formed by dashed lines indicate less strict patterns named digressive groups (Figure 2):

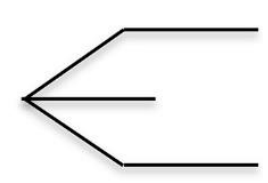

Figure 1. Graphic tool for expositive group

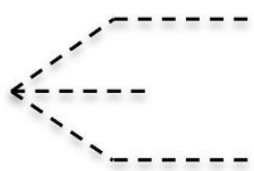

Figure 2. Graphic tool

for digressive group

There are two other kinds of grouping, all of them with non-imitative structures. The first, which we call polyrhythmicgrouping, occurs when voices have the same text, but in cross-rhythmic relation. This grouping is indicated with a square rectangle (Figure 3). The second, homorhythmic grouping, occurs when voices have the same text and the same rhythmic structure. This is indicated with rounded rectangles (Figure 4):

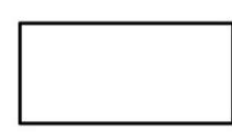

Figure 3. Graphic tool for polyrhythmic grouping

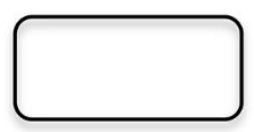

Figure 4. Graphic tool for homorhythmic grouping

Another kind of grouping, contrapuntal construct, is a useful tool in three non- or quasi-imitative situations (Figure 5): a. when a non-imitative melodic fragment is used as free counterpoint to an imitative one; $\mathbf{b}$. when voices form a non-imitative grouping; and c. when an imitative group has a non-imitative prolongation:

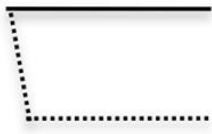

Figure 5a.

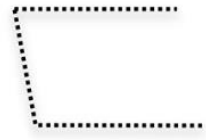

Figure $5 b$.

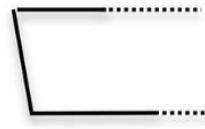

Figure 5c. 
Some words are highlighted by doubling, and are indicated by a smooth vertical line connecting a melodic fragment to a double line below it (Figure 6).

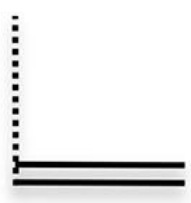

Figure 6. Graphic tool for doubling

\section{Analytic tools applied to the transcription of the two motets}

\subsection{Willaert's motet "Magnum haeretitatis mysterium"}

The opening verse is an exordium for both poetry and music. Its correlate cantus firmus have melismatic and syllabic patterns borrowed from the plainchant, and is entirely developed in the cantus voice and so are all the verses of the antiphon, with some exceptions noted by Rivera (1993). For the first word, "Magnum", we see that a melisma segment is doubled a third below in the immediately lower voice, the altus. This doubling is preceded by a transposed imitation a fifth below, in altus and tenor, granting the word "Magnum" a wider dimension which reflects its meaning. The next fragment, haeretitatis, is stated as a paraphrased motive in the tenor forming a contrapuntal construct with a bass line that leads to an ornate cadence in C (per transito); the construct is then imitated a fourth above, leading to a cadence in $\mathrm{F}$ (also ornate and per transito), but with the motive in the altus, while the bass performs an identical counterpoint. The contrasting shapes of the CF fragments "magnum" and "hereditatis" are related to the different imitative textures that evolve from them (Example 15).

This leads to the word mysterium, where a non-imitative grouping unfolds over a polyrhythmic pattern of melisma in the lower voices. This is followed by a staggered cadence that ends the exordium in an almost full fashion. 


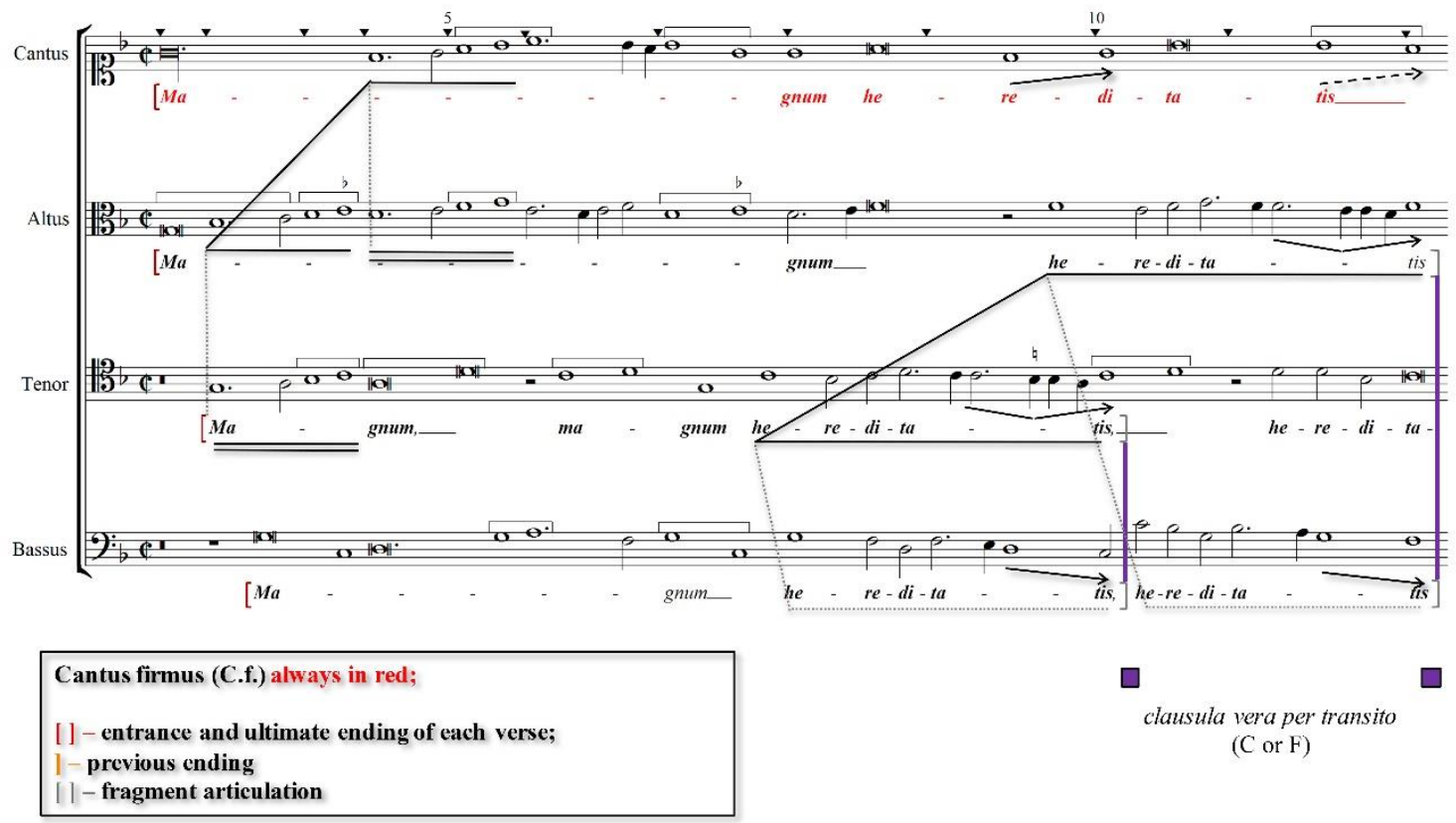

Example 15. Exordium: "Magnum hereditatis"

The next verse begins with "templum Dei factus est" as an expositive duo at the octave between the tenor and cantus, the latter bearing the CF. This process is reinforced by doubling the tenor a third above in the altus, and through digressive imitations in the bassus that work as a virtual building foundation (Example 16):

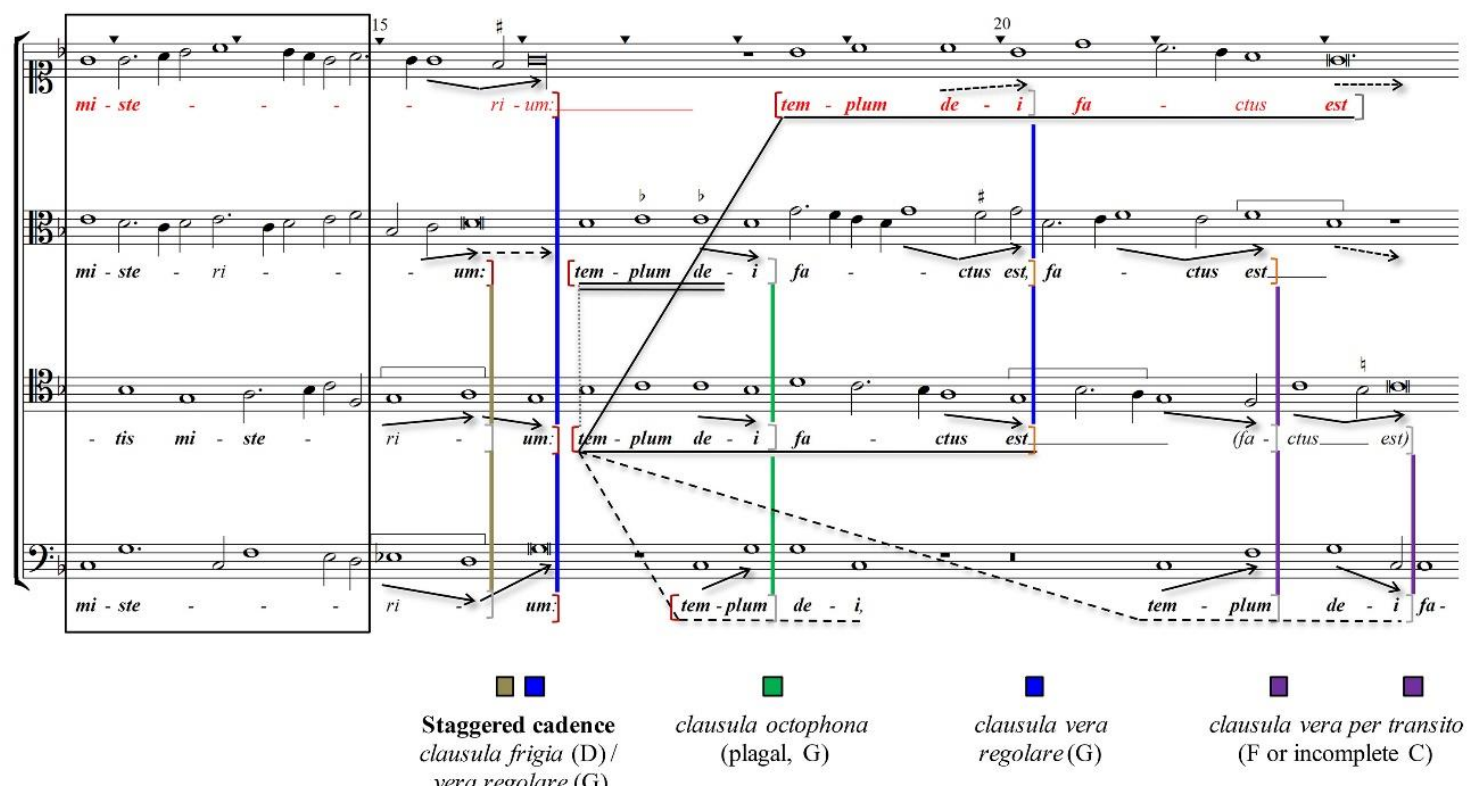

Example 16. "mysterium and templum Dei factus est" 
The verse extends through the section "uterus nesciens virum" changing its texture by means of multiple polyphonic resources. A contrapuntal construct paraphrases the $\mathrm{CF}$ in the cantus, establishing cadential correlation with a polyrhythmic grouping. The latter is followed by an imitation of the construct, coordinated by a non-overlapping expositive duo between cantus and tenor. Both imitative constructs are similar and have the same finalis. According to Rivera, in this moment the CF fragment "nesciens virum" migrates to tenor, even though the author fails to mention the word 'uterus'. From a point of view this may be true, since a rest detaches the two related fragments; moreover, "uterus" in the cantus could resolve in a strong cadence with the bassus, considering the ficta over it. On the other hand, Rivera's criteria could lead to ambiguity, since all the voices pronounce the complete text until the end of the cantus motive; but the fact that Rivera locates it on the tenor coincides with its final occurrence in the complete section. This ending occurs with an additional contrapuntal construct just above, involving only the words "nesciens virum". As a consequence, the words "uterus" and "nesciens" are partially superimposed, creating a diverse textural scenario suggesting the purity of Mary's body (Example 17).

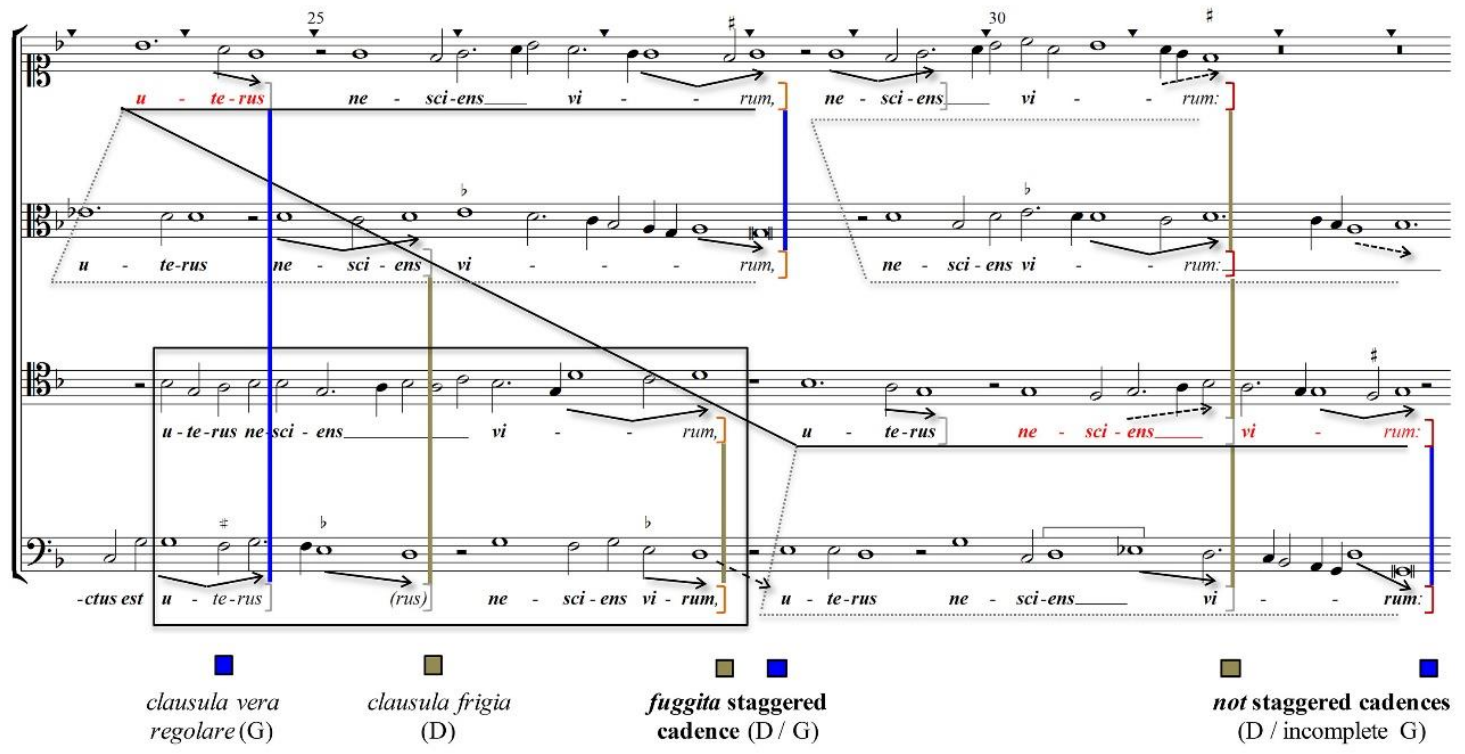

Example 17. "uterus nesciens virum"

The following verse "non est pollutus ex ea" (Example 18) could also be a symbolism for purity, but now relative to the incarnation of Jesus. As a way of changing the previous texture, Willaert creates a series of paraphrased motives in stretto, beginning with the tenor in overlap with the previous verse, but not yet as a complete motive; this will happen, in fact, in the first imitative duo between altus and bassus, including the fragment "ex ea". This appears to be an expositive grouping, due to the similarity with the last grouping of this section, which 
features the CF in the cantus, paraphrased in the tenor a fifth below. The second duo of this section is digressive, with imitation at the octave, while the third is the most digressive, due to its larger temporal distance and modified paraphrase; nevertheless, it plays an important role in the staggered cadence that ends the section. This larger set of groupings indicates the rhetoric value of repetition in this section.

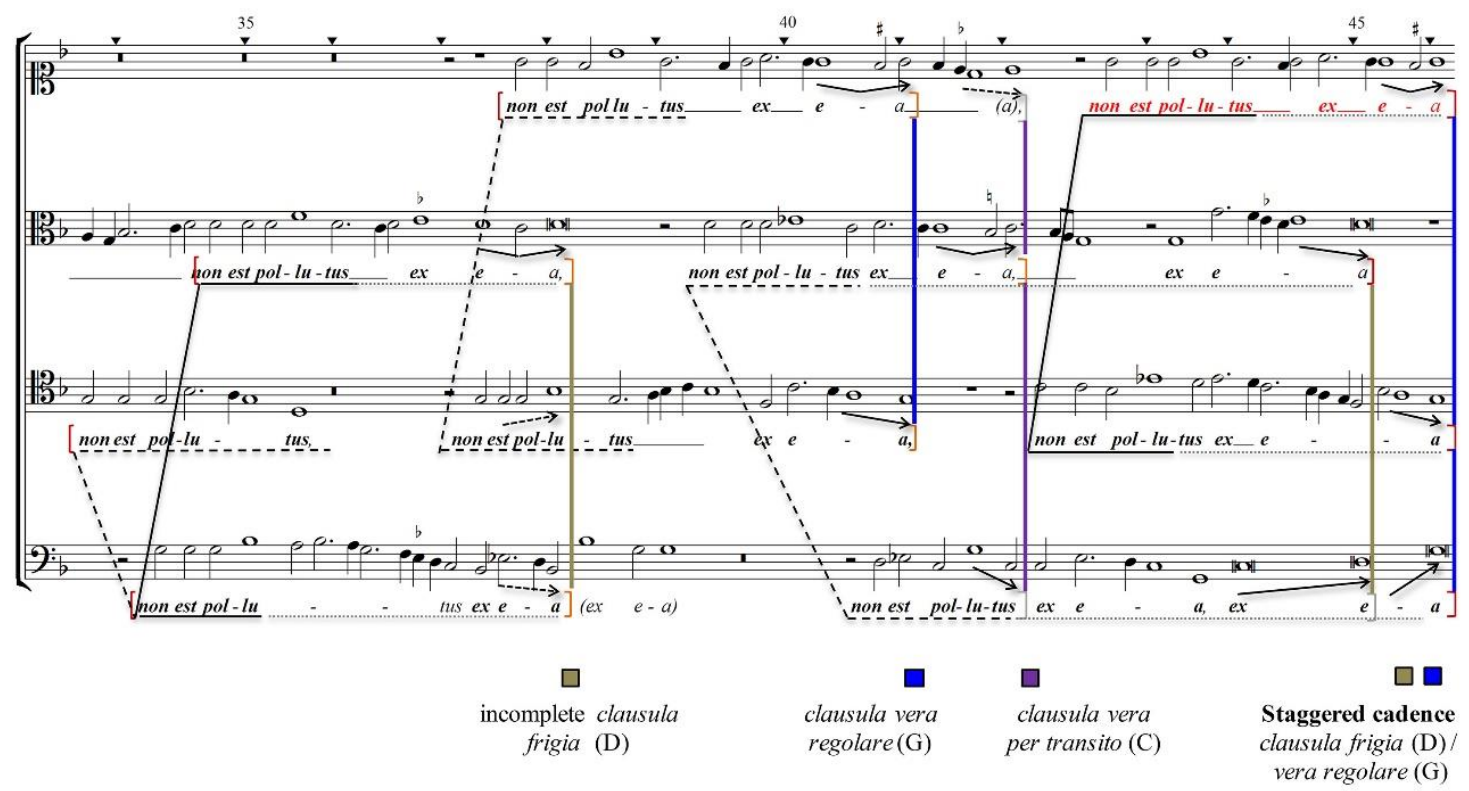

Example 18. "non est pollutus"

The next fragment (Example 19), "Carnem assumens", undergoes imitative grouping in stretto with doubling in the tenor. A similar strettogrouping occurs by means of invertible counterpoint, implying spatial rotation with an axis on the altus. After the second duo, a digressive motive enters in the cantus voice, coordinating a staggered cadence that concludes this section in a way similar to the previous one. The entire procedure grants the word "carnem" an even more dramatic meaning as a central core of the verse. 


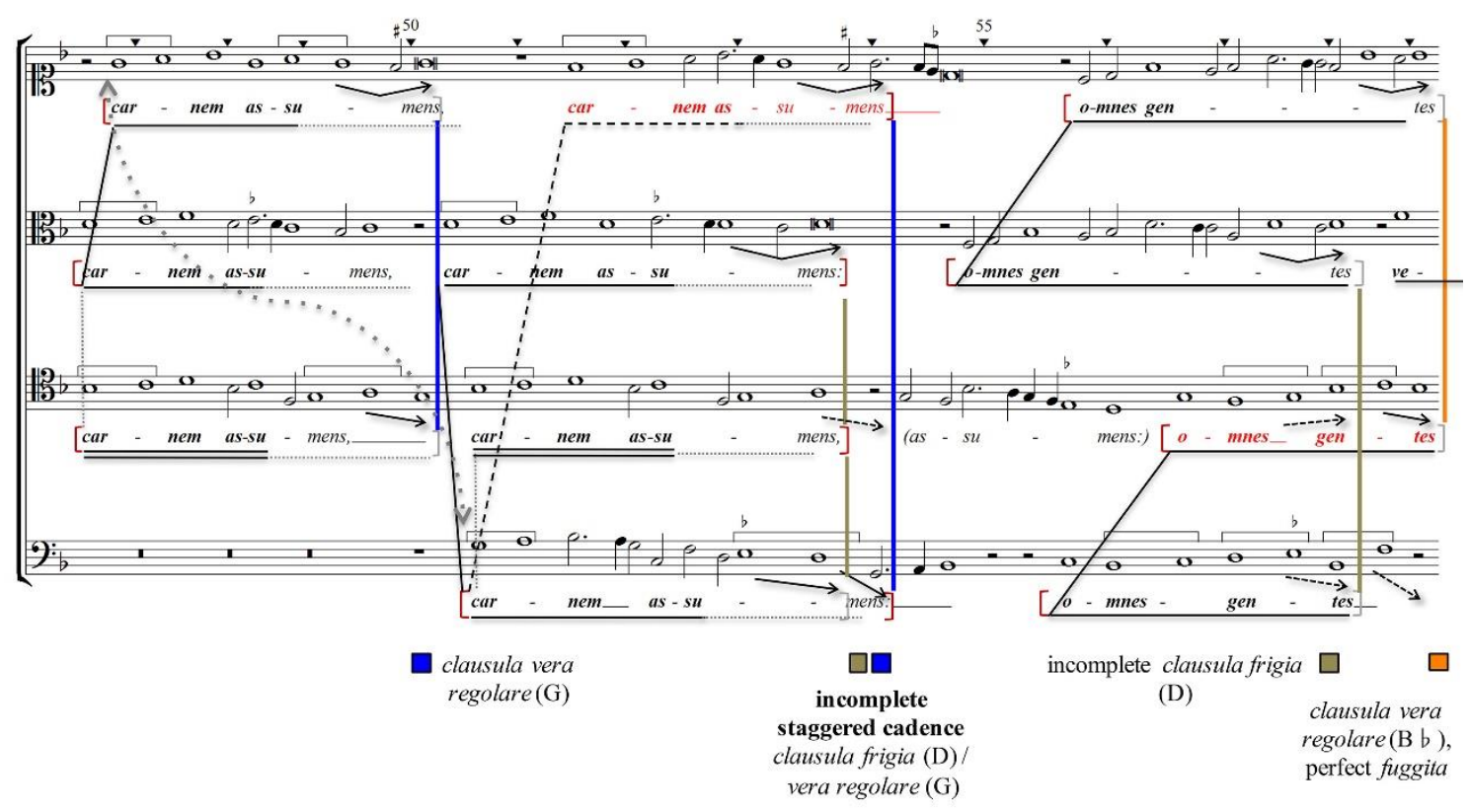

Example 19. "carnem assumens"

As revealed by the structure of the motet, staggered cadences create strong articulations mainly at the end of the verses. However, they will occur again only at end of the motet. This could reflect a change in mood for the discourse, once the dramatic verses are already exposed. No strong cadence is found for the terms "omnes gentes" and "venient dicentes", which feature only regular cadences (segunda and intermedia) out of the finalis. "Omnes gentes" is stated by two superimposed imitative duos, each with a different motive, but strongly correlated by cadential connections. By force of overlap relations, the CF can't be located in another voice than the tenor, as presumed Rivera. These imitative features may suggest the sense of multiplicity inherent to this expression.

Differently, "venient dicentes" (Example 20) features a diverse imitative web by interweaving an expositive duo and a digressive one, beyond a homorhythmic duo between altus and bassus. Such diversity favours the sense of plea of this repeated expression. 


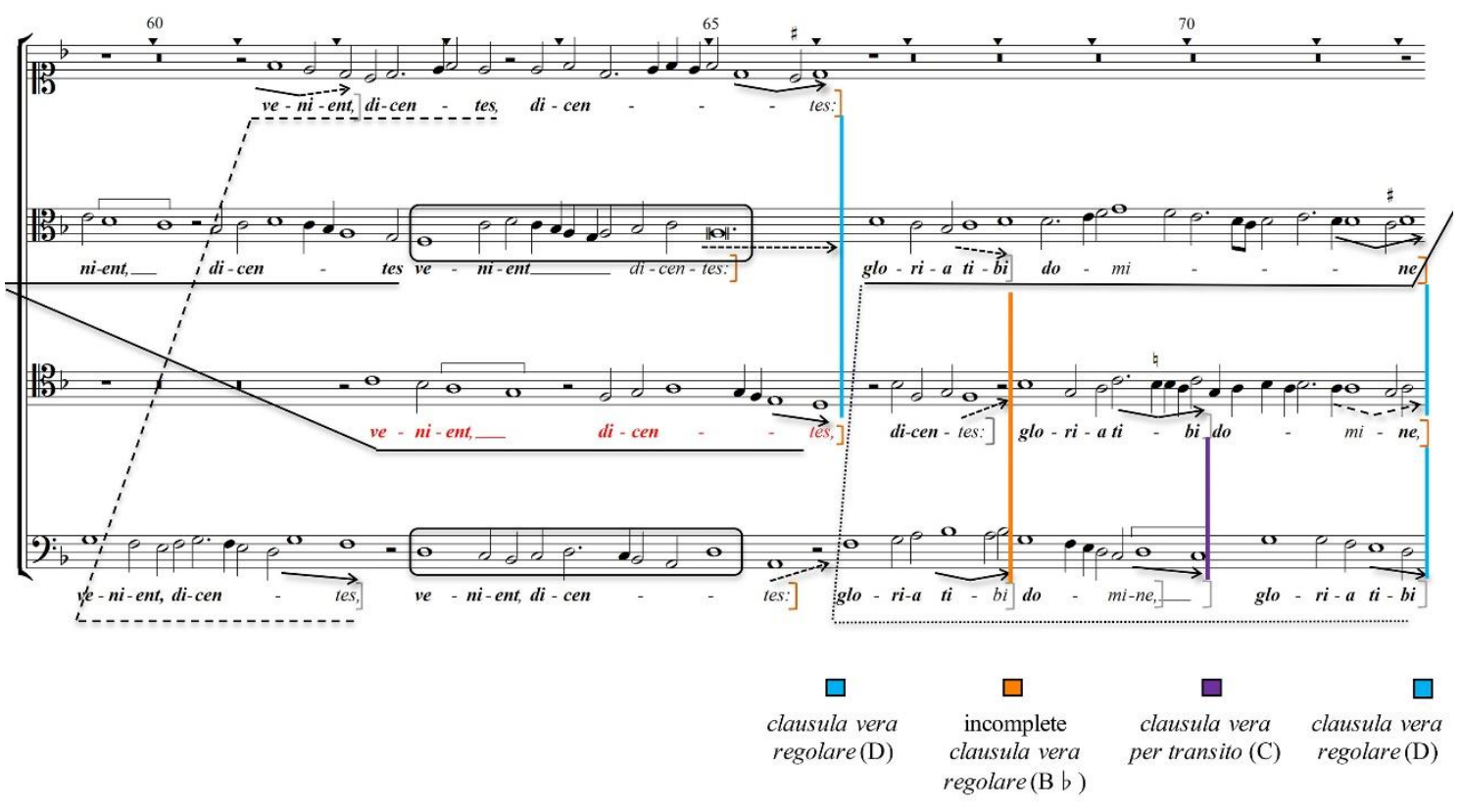

Example 20. "venient dicentes

The weak articulation produced by the cadences before "Gloria tibi Domine" suggests that this is consequent to the latter section, rather than an isolated verse. It is organized through a threefold shaft of articulated expositions comprising altus, cantus and altus again (Example 20-21).

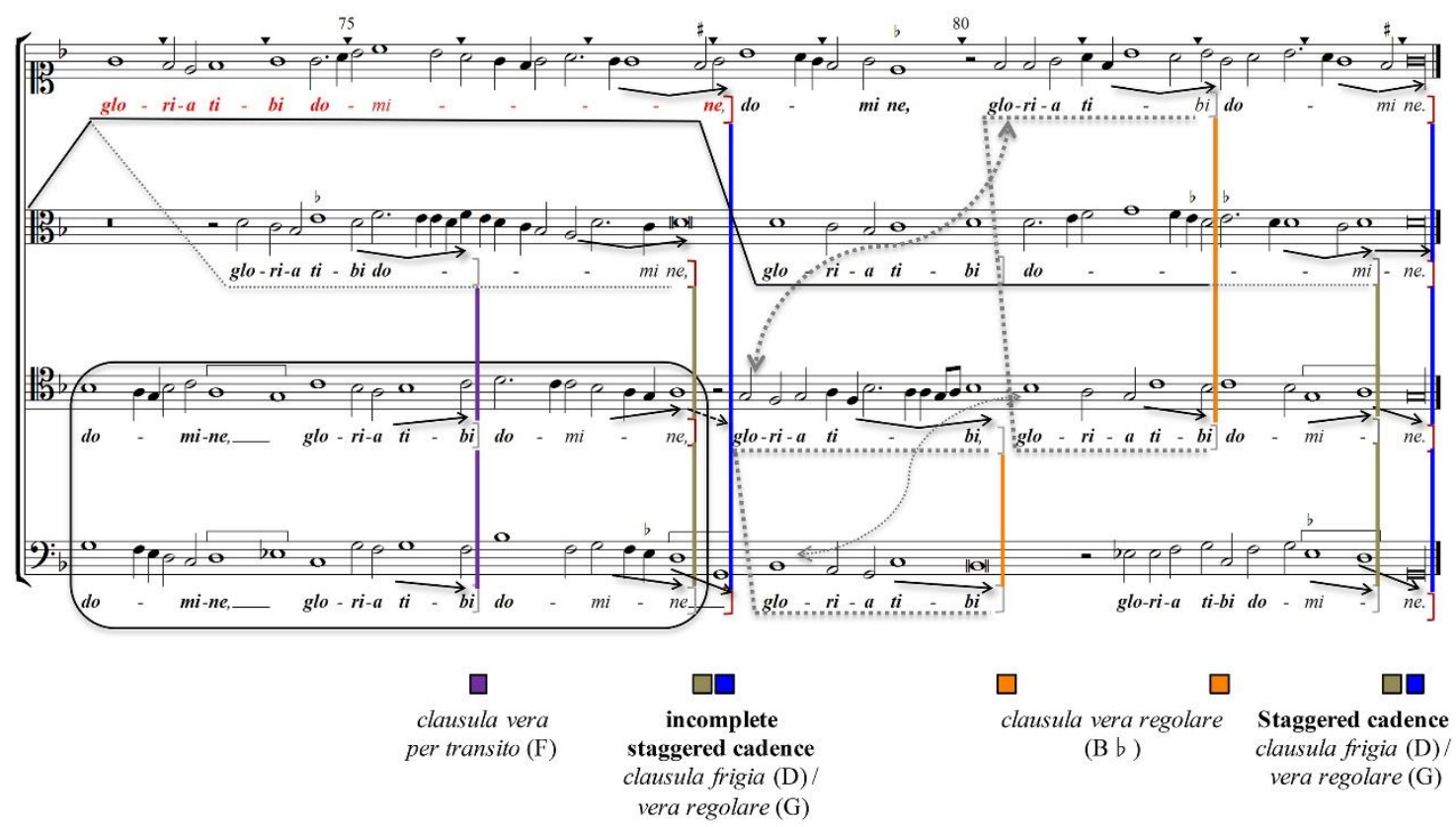

Example 21. "Gloria tibi domine"

The first altus section coordinates a contrapuntal construct with the lower voices, ending in D over a weak clausula vera (Example 21). 
The cantus section bearing the $\mathrm{CF}$ ends in a strong staggered cadence in G. Under the CF, two superimposed processes replicate the text (Example 21). One of them, a homorhythmic group, is composed by tenor and bassus. The other, a contrapuntal construct, is done by the cantus and altus.

The final altus motive conducts a phrygian cadence in $\mathrm{D}$, this being in turn only a component of the concluding staggered cadence. Two successive contrapuntal constructs dialogue with this last part, the first formed by tenor and bassus, the other consisting of an imitation at the octave by cantus and altus. The large expositive axis (Example 20-21) and the symmetrical layout of the final groupings are a musical solution that favours the reiteration of this expression of piety. The words are equally distributed throughout the polyphonic texture by means of a solid framework that concludes the motet.

\subsection{Analytic tools applied to the transcription of the Clemens's motet "Venit vox de coelo"}

As indicated in Figure 1, four partbooks of this Clemens's motet are incomplete. For the earliest, "Stonyhurst partbooks", only the quintus and the septimus voices are extant. Although the contratenor part for "Motetti del laberinto" is lost, this source remains useful. The other two, HradKM 29 and RISM $1559^{5}$, have only the bassus voice; therefore, they were disregarded.

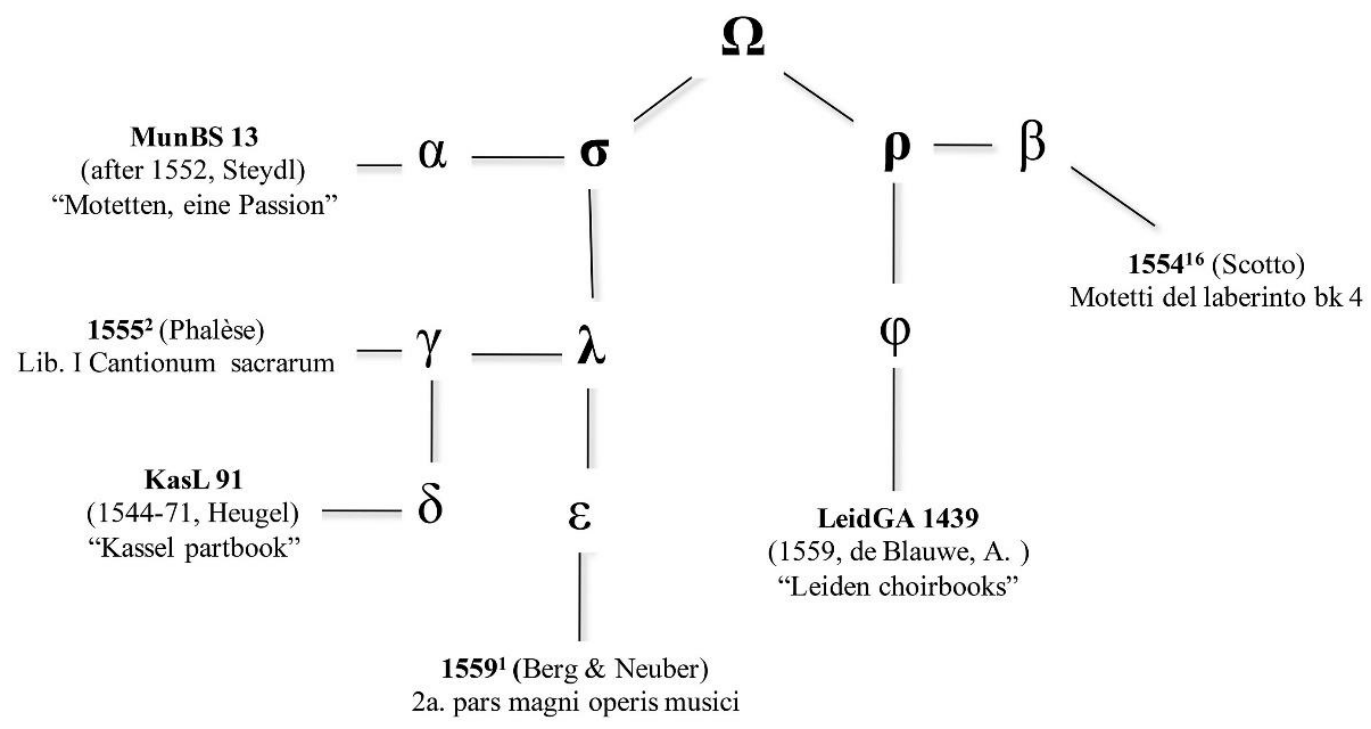

Figure 8. "Venit vox de coelo": stemmatic proposal

The careful observation of these primary sources showed some differences in terms of text placement and note arrangement. So, we were able to select them by similarities, and to propose a possible stemmatic relationship (Figure 8), 
which is yet over evaluation. Two distinct branches, " $\sigma$ " and " $\rho$ ", accommodate sources selected by means of significant "errors" (id est, separative, conjunctive, or no distinctive errors). According to Iain Fenlon, all pieces contained in the "Munich choirbook" circulated in print before 1552; it follows that the number of hyparchetypes must be larger.

For the text placement conventions in primary sources, bold italic texts refers to the exposition of an inscribed verse; regular italic texts refers to a repeated inscribed verse; and texts in gray refer to an indicated (or inferred) verse repetition (Figure 9).

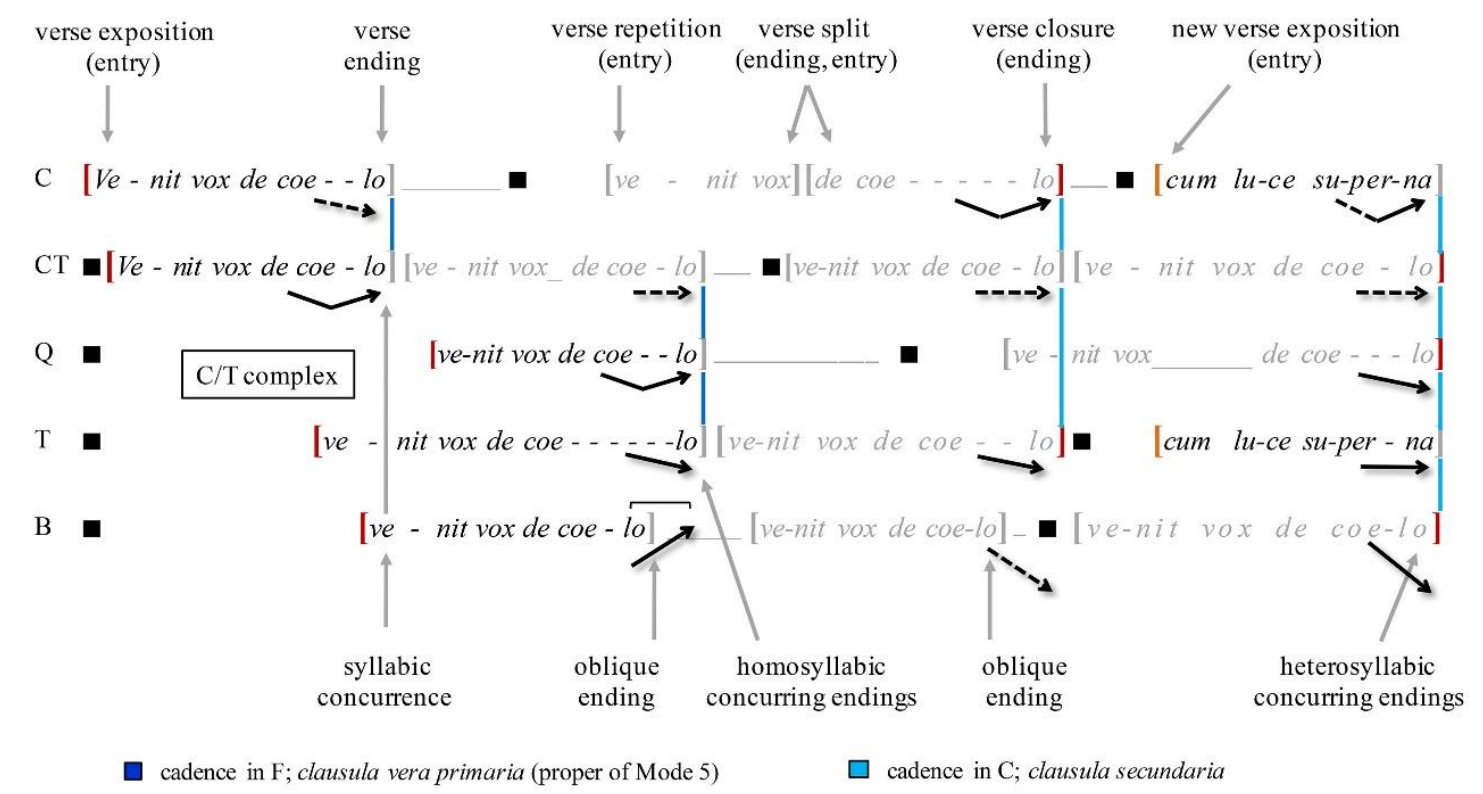

Figure 9. Schema of the voice setting for the first verse of the motet, corresponding to its exordium - articulation symbols

In this representation, pairs of colored brackets indicate the length of the verse in each voice, opening at the entry of the verse exposition and closing at the verse closure. Entries for verse repetition are marked in gray, just like the verse endings before them. Verse splitting also occurs in other verses of the motet; this is just an example. The exposition of a new verse is marked with a change in color at its entry.

The standard condition for a clausula hexaphona $a^{3}$ (intervallic resolution from $6^{\text {th }}$ to $8^{\text {th }}$ ) is the link between cantizans and tenorizans (or C/T-complex, as we call it), although alterations might be present, such as in the first verse ending. This is followed by another C/T complex, reinforced by an altizansfuggita at the verse ending and by the basizans' motion at the semibreve ligature. Colored vertical lines show two subsequent cadences in F (in deep blue), and also serve

${ }^{3}$ Burmeister's terminology, similar to C/T clausula. (RIVERA, 1993b) 
to highlight syllabic concurrence between voices, which promotes textual articulation at discrete levels. Two other cadences follow, with their resolution in $\mathrm{C}$ reinforced by the basizans' motion, the last one in a complete fashion, but the one preceding it as a cadenza fuggita. This results in an oblique ending in the low voice, preventing syllabic concurrence at the articulation; the same occurs previously, due to the ligature. Thus, it seems that the modular pattern for these articulations can be controlled by the profile of the cadence and either through homo- or heterosyllabic concurrence at verse endings.

Like the analysis for Willaert's motet, the grouping structures are defined according to motivic imitation in a shared minimal configuration, with the aid of some graphic tools we devised to this end. Thus, horizontal solid lines were drawn under each staff, with diagonal lines connecting the beginning of the first entry to the beginning of each imitation. Such grouping structures following a regular pattern are defined as expositive groups, whereas grouping structures formed by dashed lines (indicating less strict imitative patterns) are defined as digressive groups. In the exordium of the Clemens's motet (Example 22) this graphics tools shows a symmetric structure at the beginning section, typical for motets in that historical period: an expositive duo followed octave below by another one with an additional entry in the quintus part (all the entries organized by the same time interval). A digressive grouping in dashed lines based on the original motive but varying shape and time entries leads to the end of the exordium.

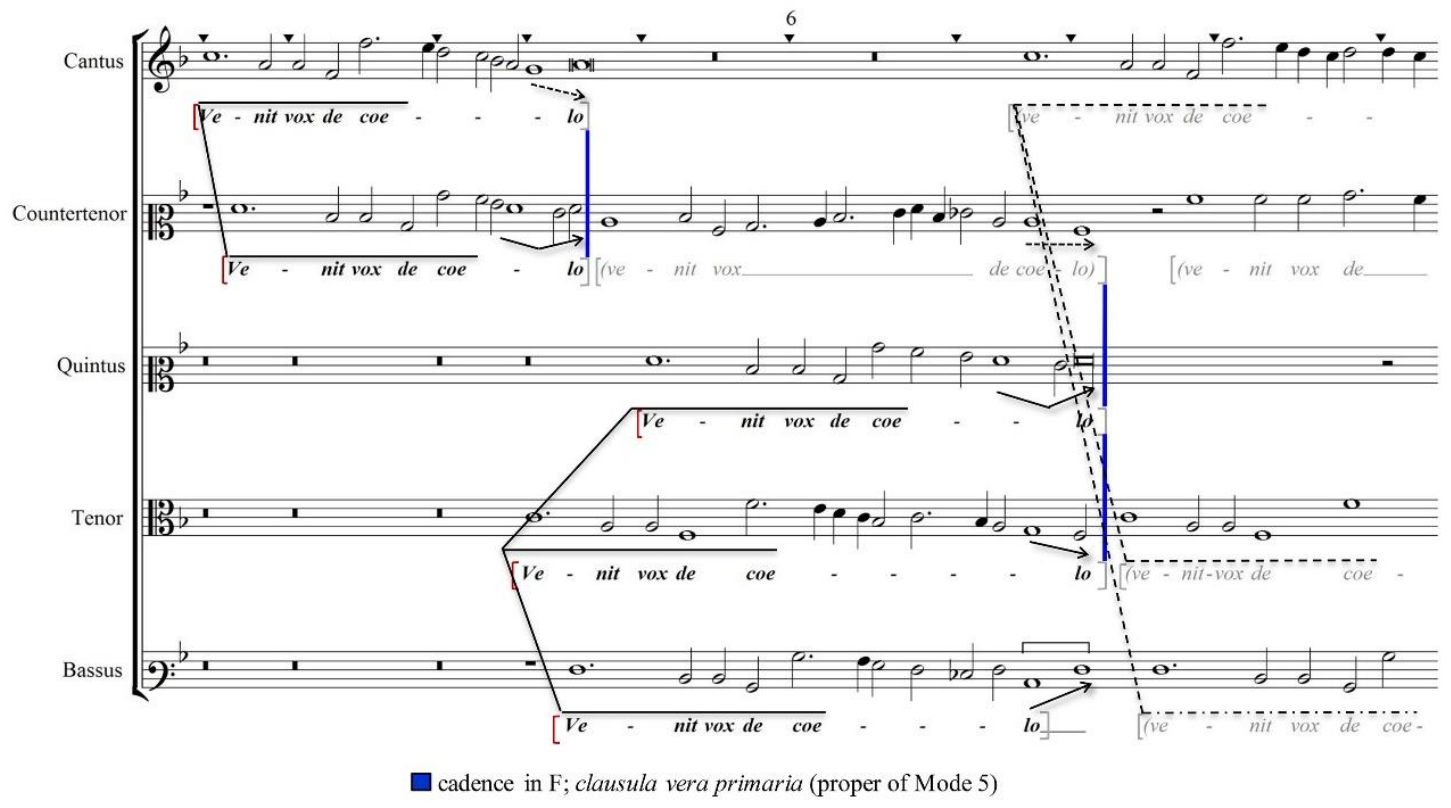

Example 22. Exordium: "Venit vox de coelo" 
The cadence plan already exposed in the previous Figure 9 matches these groupings, each concluding with a C/T-complex, and eventually with other melodic formulas.
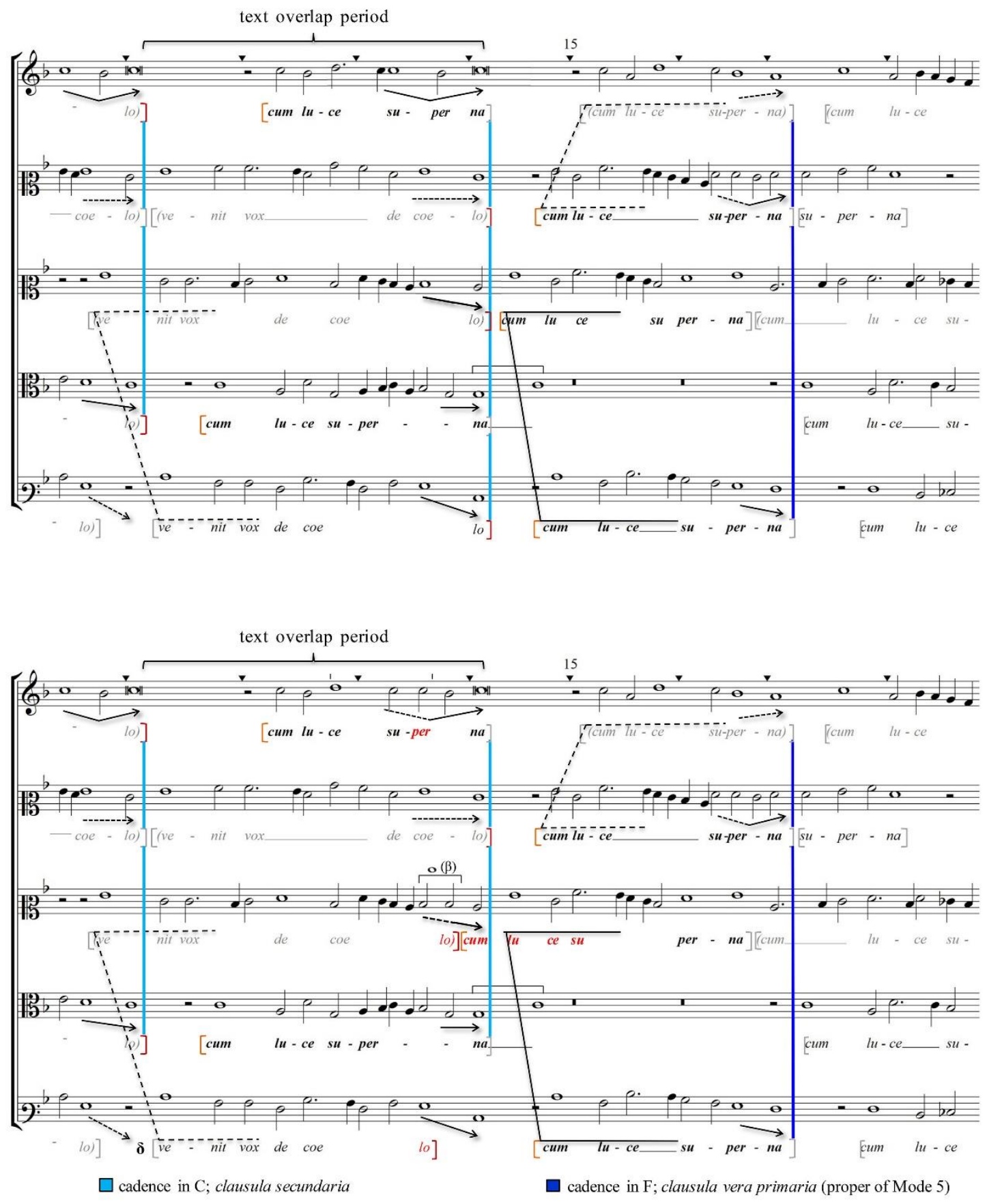

Example 23. Two alternatives analyses for the same fragment: "cum luce superna"

Intensification occurs towards the next articulation (Example 23), a cadence in $\mathrm{C}$ involving verse closure by the C/T-complex and homosyllabic 
concurrence (see that for the first time the melodic formulas assume their original voices). The beginning of an additional digressive group anticipates this cadence, and new verse entries for "cum luce superna" overlap with the closing "venit vox the coelo" voices to arrive at a full closure. This overlap period characterizes the transition between the exordium and the medium section. Here, it is remarkable that only Scotto's edition $(\boldsymbol{\beta})$ presents a typical clausula formalis (the superior fragment in Example 23), other scribes preferring to manage this articulation with diminutions in the C/T-complex (inferior fragment). This attenuates the effect of the cadence and causes syllabic displacement both in the cantus as in the quintus, where the verse closure becomes oblique at the cadence for the latter. In addition, the Kassel partbook $(\delta)$ suggests oblique endings for the bassus (inferior fragment) that obscure the articulation point at measure 13 (compare each voice in both alternative analysis).

After the text overlap period (Example 23), new expositive and digressive groups in stretto create a suitable reverberation for the verse "cum luce superna", ending with a heterosyllabic articulation in F. This is followed by a stronger homosyllabic cadence in F (see Example 24) again with the C/T- complex in its original voices, leading to a text overlap period that concludes the verse in C. In the same example, the next verse "super Saulum dicens" is structured on a freer counterpoint and a more fragile imitative texture, with a linear imitation in the bassus. Its first cadence in $\mathrm{F}$ and the following in $\mathrm{G}$ - a cadenza peregrina in which the $\mathrm{C} / \mathrm{T}$ complex fits one more time with its original voices - generate a local cadence plan that resembles that of the previous sections.

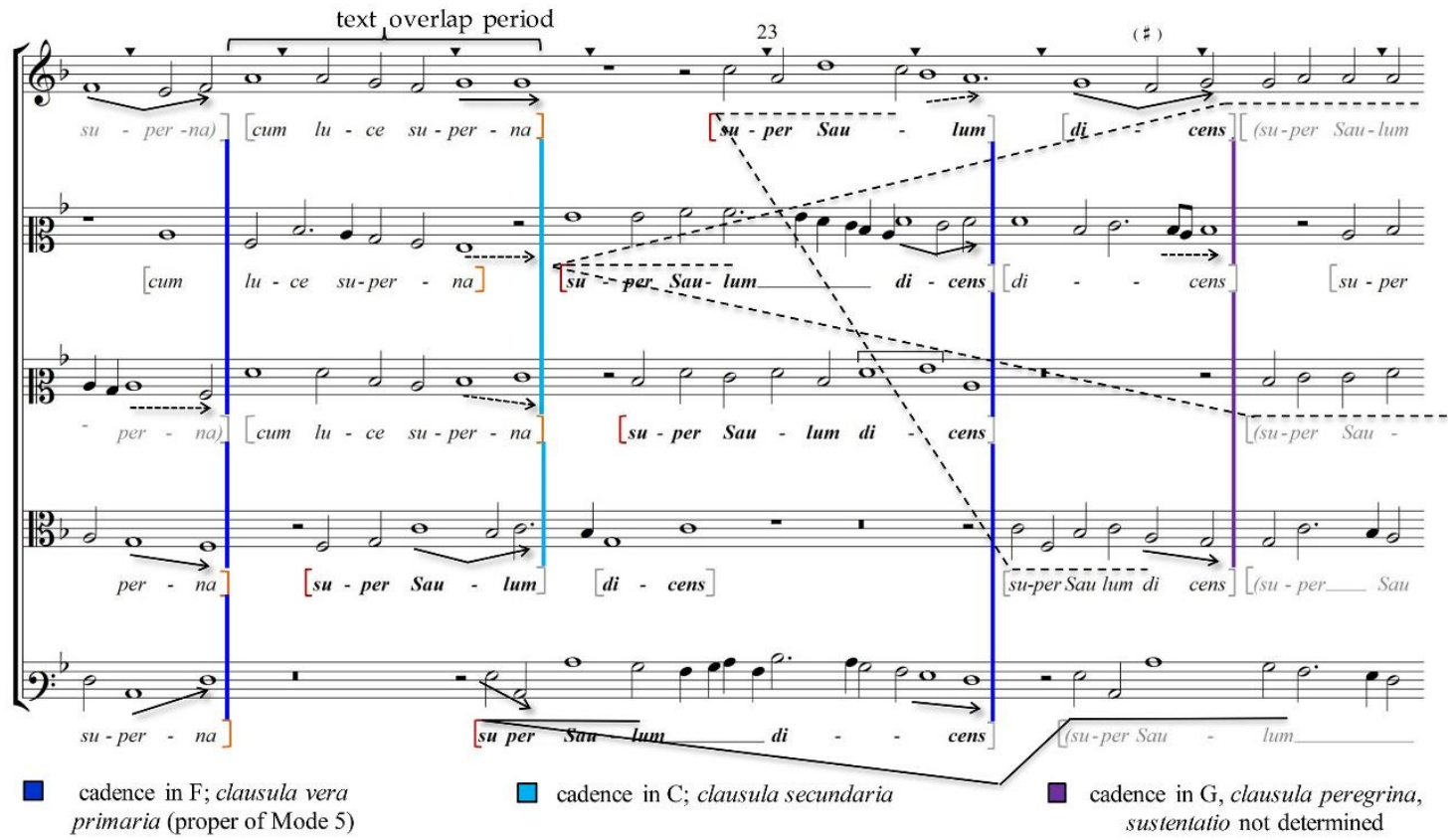

Example 24. "super Saulum dicens" 
By means of that, a common basis is established for the narrative discourse up to its ultimate articulation (Example 25): a full homosyllabic concurrence conducted by a double parallel C/T-complex, where quintus and bassus perform a clausula vera in $\mathrm{F}$ while Cantus and Tenor undergo a clausula frigia in A (measure 28 ), both of them formalis. This opens a section in which Saule is called by the celestial voice of Christ. In a new scenario, an unprecedented plagal cadence in $\mathrm{F}$ leads to mosaical authentic and plagal cadences in $\mathrm{C}$ and $\mathrm{F}$ (in green and blue on the chart) whose parallel movement suggests the allegory of celestial voices. This section also displays a more complex imitative texture: the continuous repetition of the name Saule is treated by Clemens with two contrasting expositive groups (measures 29-32) and a digressive group imbricated with them. This intensifies the effect for these celestial voices, projecting the name Saule in two different plans.

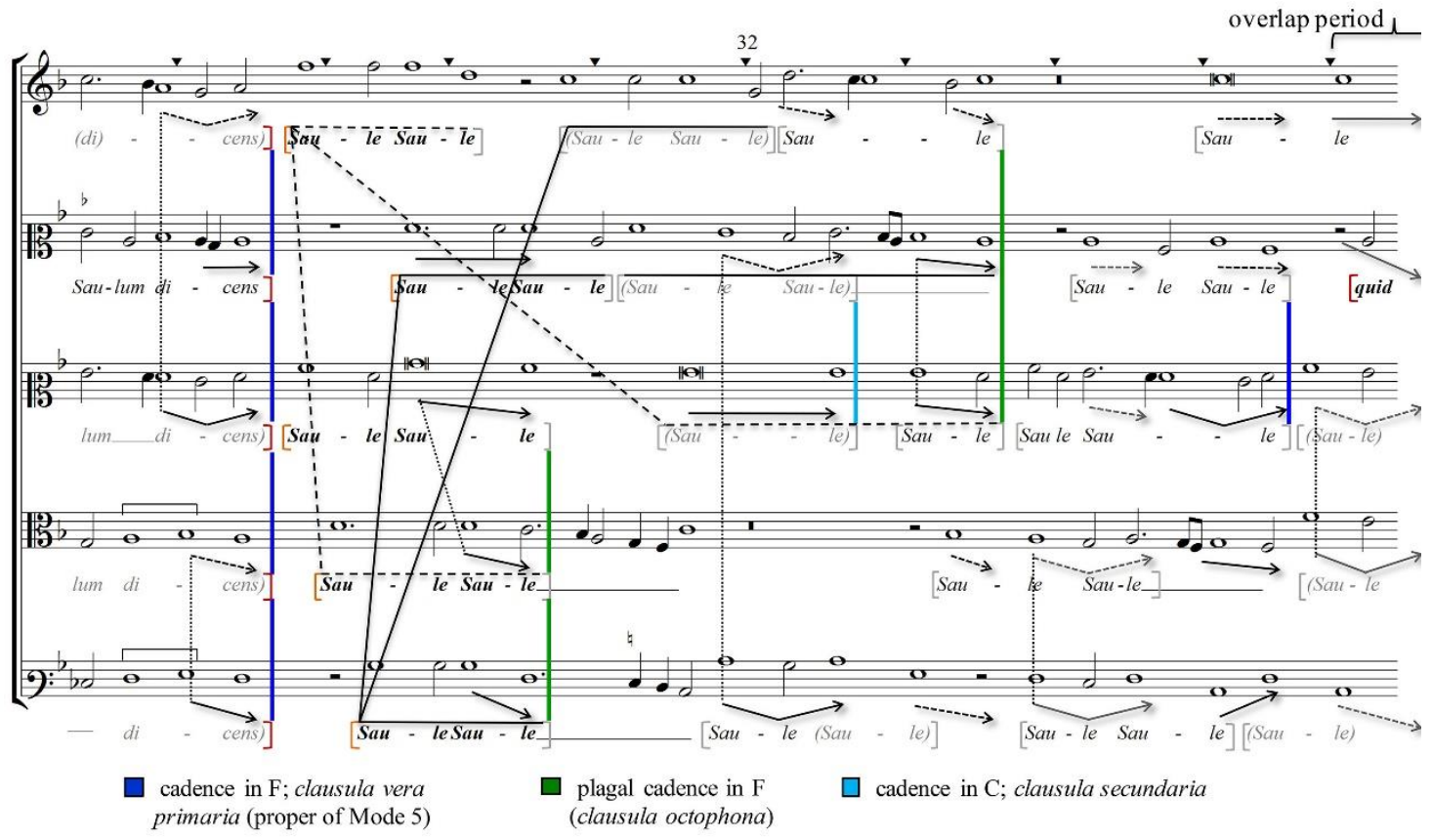

Example 25. "Saule Saule"

Then it follows a short overlap period between "Saule Saule" and the new verse entry "quid me persequeris" together with a plagal cadence in $C$, in brown (Example 26). This is followed by additional new verse entries in strict imitation, providing a more inquisitive discourse for the section. Three sequential expositive groups for "quid me persequeris" (Example 26 and 27), each involving four or five voices, are separated by the same time span (18 half notes). The first two are in a more symmetrical fashion, differing only by one additional entry in the second group; they are followed by cadences in $C$ with homosyllabic endings, which serve to coordinate pairs of entries in each group. This process creates a 
new rearrangement for the grouping structure, allowing a functional interpretation of its assembly towards dismembered articulations (inferior fragment below at Example 26 and 27).
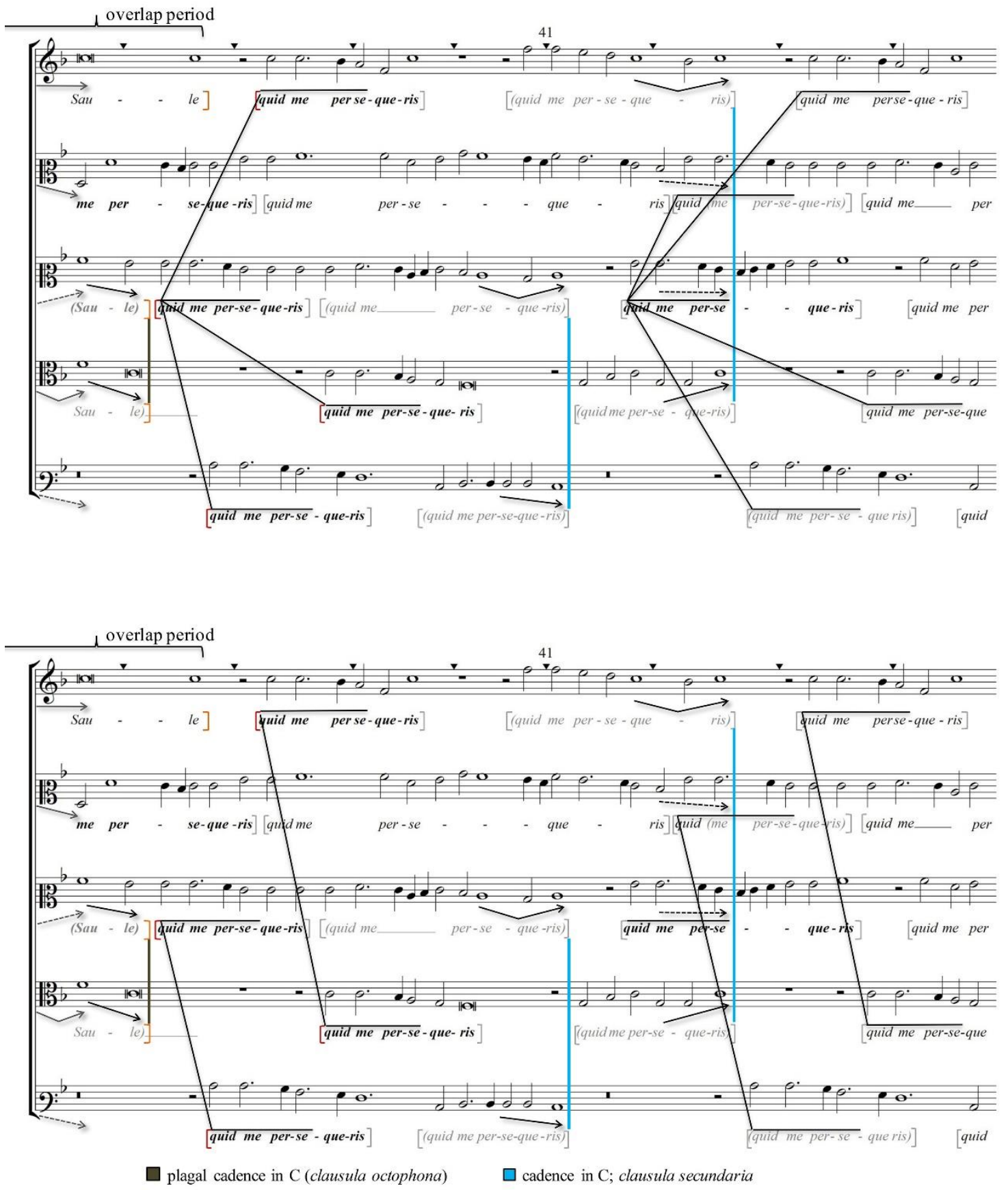

Example 26. Two alternative analysis for the same fragment "quid me persequeris" 
For the last "quid me persequeris" group (Example 27), one sole pair is governed by a C/T complex, reflecting a lesser degree of motivic symmetry but otherwise reinforcing a concurrent verse closure in the tenor. The cantus voice introduces a rhythmic variation of motive "quid me persequeris" (measures 5053) towards the final cadence of this section in $C$, which overlaps with the "durum est tibi" verses that open the dramatic core of the text.
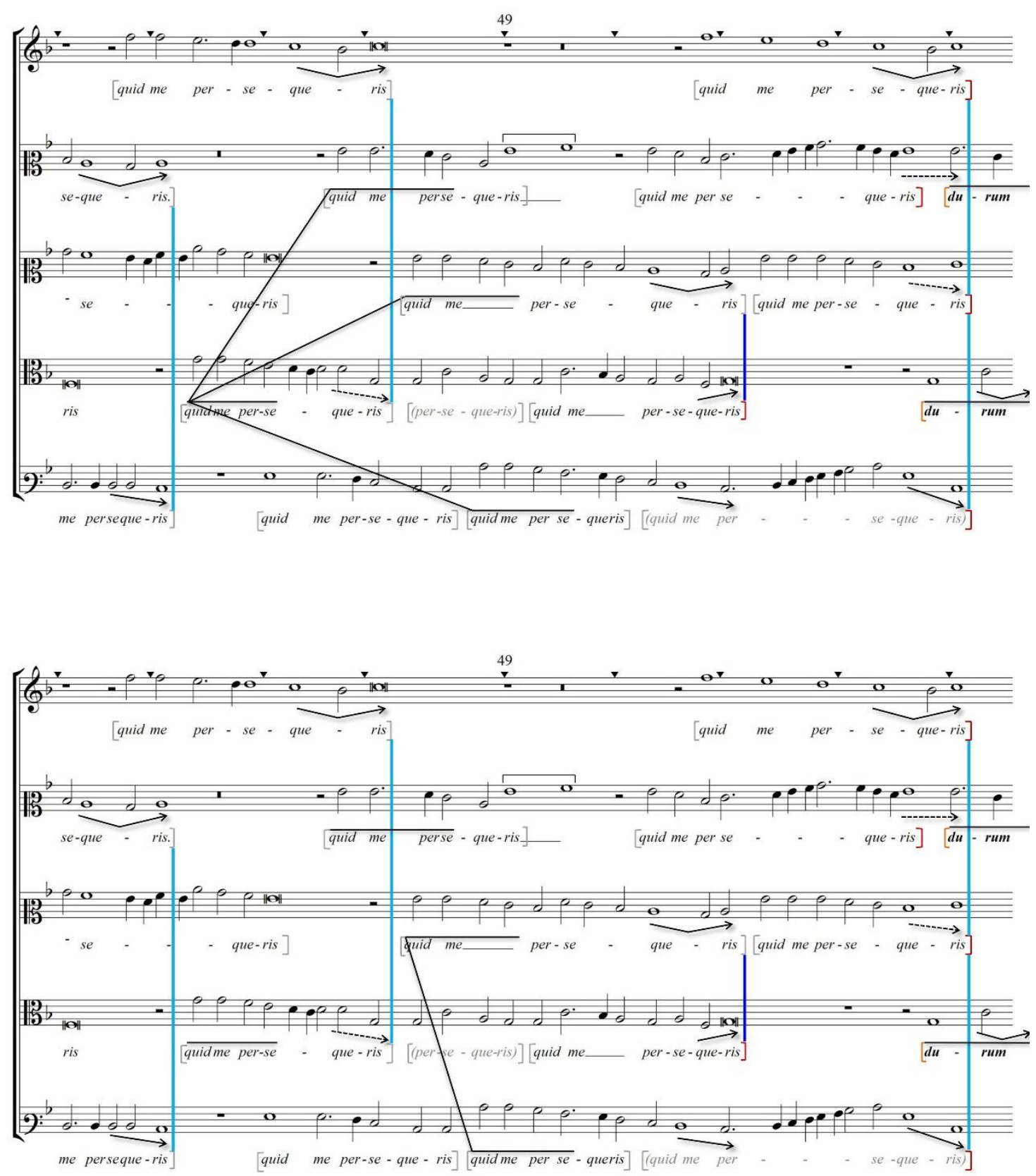

$\square$ cadence in C; clausula secundaria

$\square$ cadence in F; clausula vera primaria (proper of Mode 5)

Example 27. Two alternative analysis for the same fragment "quid me persequeris" (the last repetition of the verse) 
The sentence "durum est tibi contra stimulum calcitrare" (Example 28-29) is split in three fragments, with alternative text placement in the cantus, in the most complex imitative pattern in the piece. Two superimposed homorhythmic - though heterotextual - expositive motives at measures 54 to 60 (with weak articulation in C) create a module with another pair of voices. This is repeated throughout the section in a cadential cascade of this module, firstly in a homotextual fashion but thence forward always as heterotextual modules. Meantime, the cantus enunciates the complete text in linear imitation, articulating stronger cadences in $\mathrm{C}$.

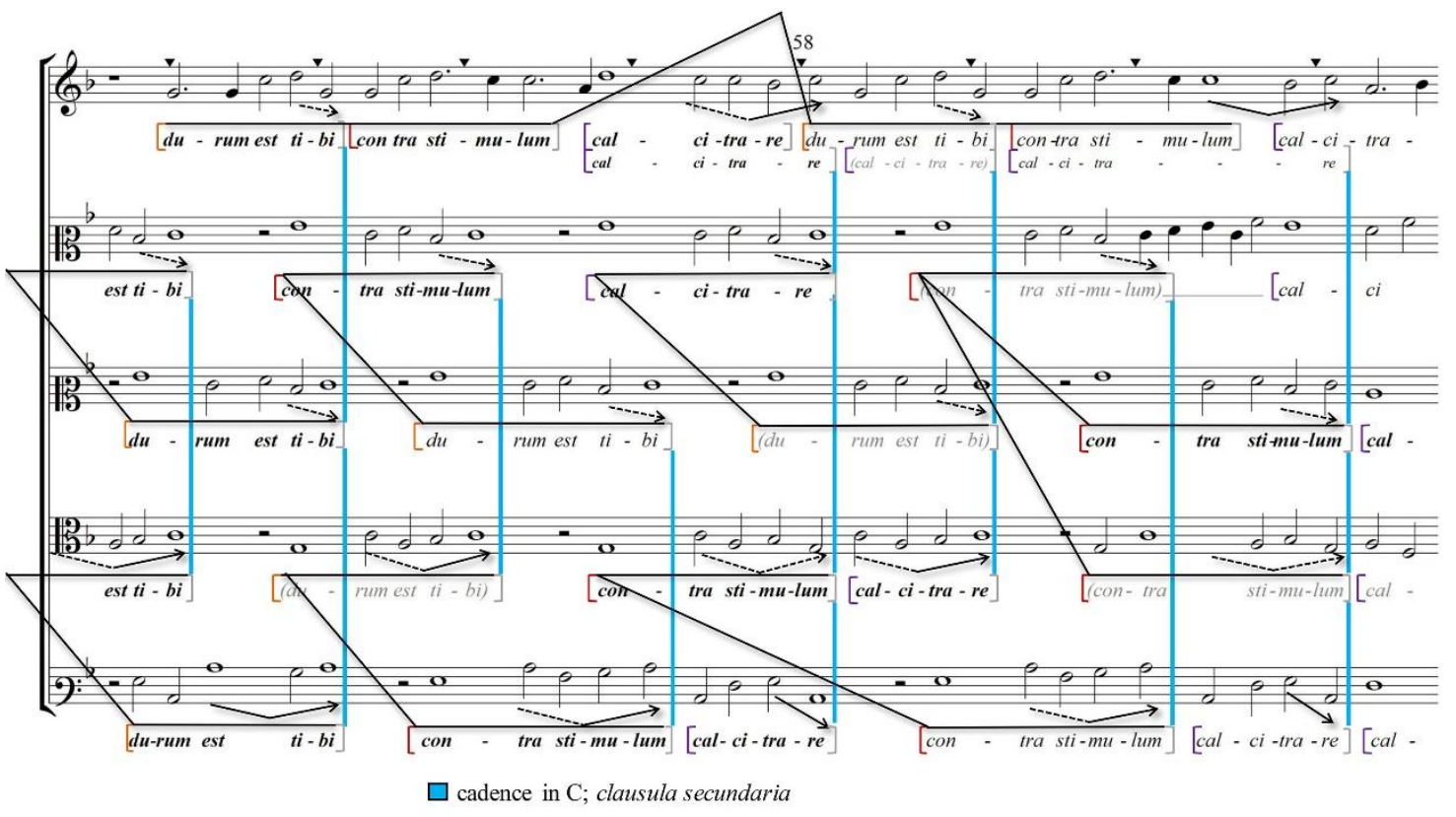

Example 28. "contra sitimulum calcitrare"

This process has a culmination point in a sole homosyllabic articulation in F with a conclusive character, albeit obscured by oblique endings (Example 29). Unconventionally, the last verse recurs, this time under two alternative texts in the cantus derived from the different lineages " $\sigma$ " and " $\rho$ ", corroborating the proposed stemmatic hypothesis (Figure 8). In the final section (Example 29 and 30) the imitations occur differently and in a peaceful manner, assembling a highly organized pair of expositive-digressive groups without any cadence between them, and avoiding text articulation for "contra sitimulum calcitrare", in opposition to the preceding complexity of cadencial and imitative patterns. 


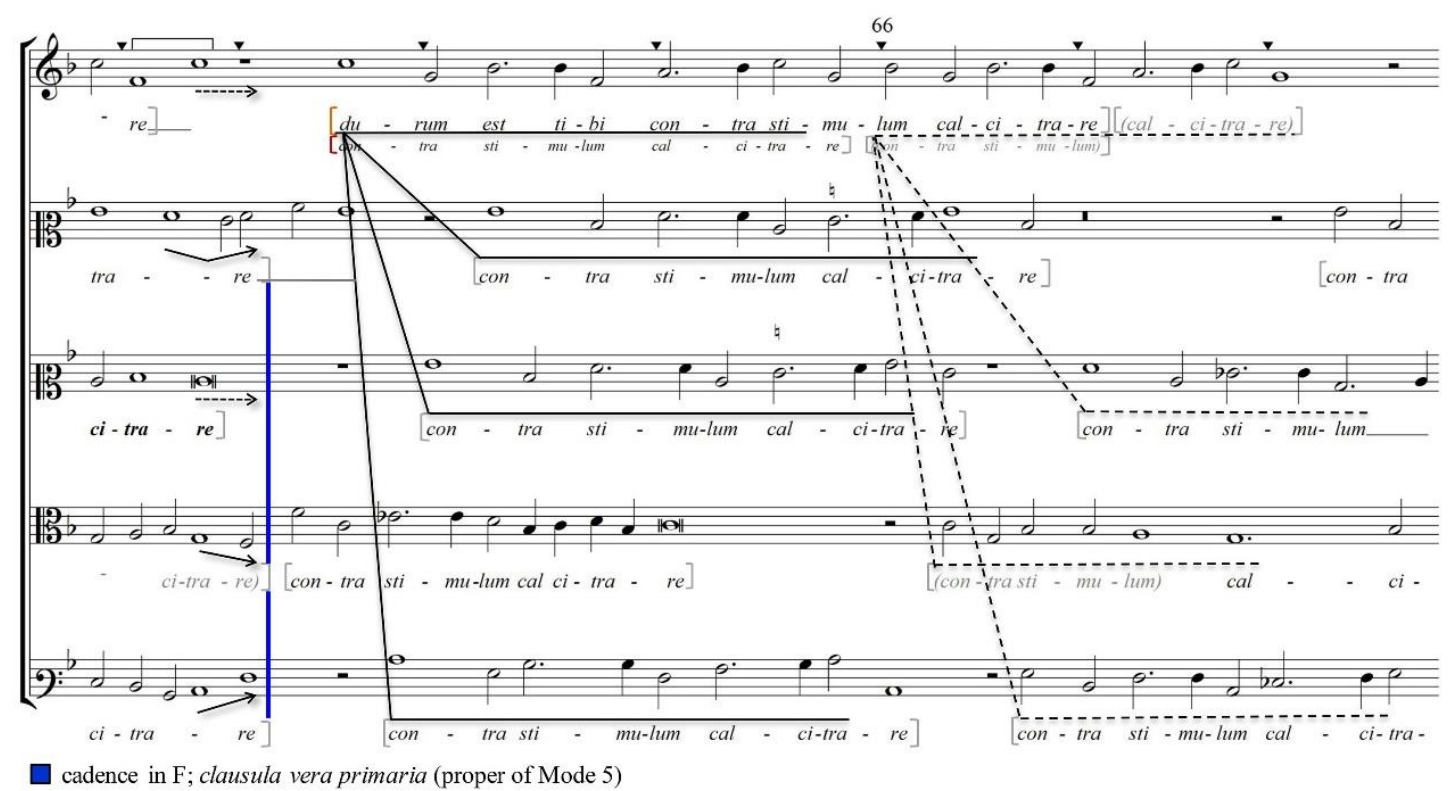

Example 29. "contra sitimulum calcitrare", continued

Just ahead, an additional pair of expositive-digressive groups (Example 30) of this kind occurs but in overlapping, similarly to the previous "cum luce superna". In the same manner, no cadence coordinates the grouping structures; however, the quintus voice closes the verse together with the tenor ultimate phrase "contra stimulum calcitrare" over a C/T-complex in a cadenza perfetta in F. This is followed by a plagal cadence that closes the remaining verses under clausula octophona in F, resolved properly in a third by cantus and bassus. This staggered articulation suggests that two discourses - one from heaven, the other from consciousness - are now in balance. 


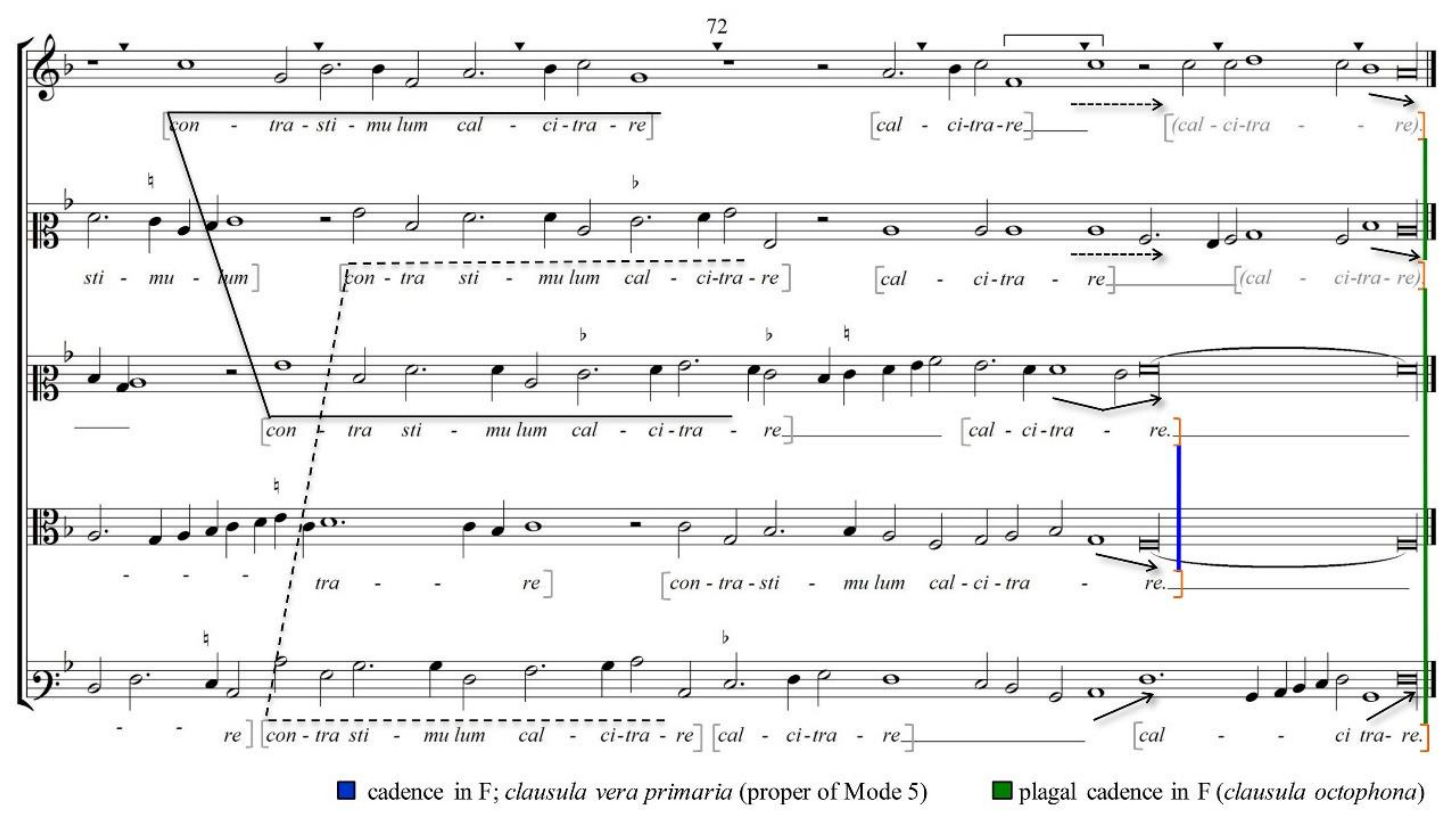

Example 30. "contra sitimulum calcitrare", continued

\section{4 - Conclusion}

The analytical tools proposed in this article suggest new perspectives to understand or to perform this kind of music in its complete textural nature. In this way, we agree with Anne Smith:

\footnotetext{
"I have come to wonder if one of the reasons that we do not often hear moving performances of renaissance music is because of our inherited concept of what renaissance music is. The pioneers of the early music movement - no matter what music was involved - were reacting to a romantic ideal, and as a result perhaps went to the other extreme, seeing $16^{\text {th }}$-century music as being something infinitely pure, even ascetic." (SMITH, 2011, p.1)
}

With the analytical tools exposed in this work we put in evidence the relationships between text and imitative polyphony by the devising of sectional cadence plans, leading to correlations between musical interpretation of the text and its articulations. This process is related with an identification of the motivic materials used in each segment of the text, differentiating between strict imitative grouping and those with digressive tendencies. In conjunction, we think that these two approaches reveal a dynamic textual modulation mediated by sections with or without overlapping, defined by the intensification of the cadences. 


\section{References}

1. Meier, Bernhard. 1988. The Modes of Classical Polyphony. New York: Broude Brothers Limited.

2. Milson, John. 2006. "Crecquillon, Clemens, and four-voice fuga". In: Eric Jas (ed.). Beyond Contemporary Fame Reassessing the Art of Clemens non Papa and Thomas Crecquillon. s/l. Brepols: Epitome Musical.

3. Nogueira, Marcos Pupo. 2014. Forma e simultaneidade na música polifônica imitativa do séc. XVI. São Paulo, 2014. Livre-Docência Dissertation. São Paulo: UNESP Arts Institute.

4. Rifkin, Joshua. 1997. "Miracles, Motivicity, and Mannerism: Adrian Willaert's Videns Dominus flentes sorores Lazari". In: Pesce, D. (Ed.) Hearing the Motet. New York: Oxford University Press.

5. Rivera, Benito. 1993a. "Finding the Soggetto in Willaert's Free Imitative Counterpoint: A Step in Modal Analysis". In: Hatch, C. and Bernstein, D. W. (Eds.). Music Theory and the Exploration of the Past. Chicago: The University of Chicago Press.

6. Joachim Burmeister - Musical Poetics - Translated, with Introduction and Notes. New Haven: Yale University Press, 1993b.

7. Schubert, Peter. 2007. "Hidden Forms in Palestrina's First Book of Four-Voice Motets". Journal of the American Musicological Society, v. 60, n. 3, p. 483-556.

8. Smith, Anne. 2011. The Performance of 16th-Century Music: Learning from the Theorists. New York: Oxford University Press. 